\title{
O CONCEITO DE IMAGEM-PRESENÇA NA ARTE DA IDADE MÉDIA*
}

\author{
Daniel Russo \\ Department d'Histoire de l'Art et d'Archeology, \\ Université de Bourgogne. Institut Universitaire de France
}

\begin{abstract}
Resumo
Este artigo propõe situar as principais correntes de leitura da imagem na arte medieval e sublinha a aparição de uma matriz original de pensamento, o pensamento pela arte, entre 1950 e 2000. No centro dessa nova épistémè, afirmou-se o conceito de imagempresença, discutido a partir de três exemplos de entre o ano mil e c. 1450 e de um diálogo interdisciplinar com a antropologia social e a filosofia das ciências.
\end{abstract}

\section{Pallavras-chave}

Imagem • presença visual $\bullet$ história intelectual.

\section{Contato:}

Université de Bourgogne

Département d'Histoire de l'art et d'Archéologie

2 Bd Gabriel - 21000 - Dijon - France

E-mail: daniel.russo@u-bourgogne.fr

* Tradução de Maria Cristina Correia Leandro Pereira. Todas as imagens mencionadas neste artigo estão reproduzidas no Caderno de imagens. 


\title{
THE CONCEPT OF IMAGE-PRESENCE \\ IN THE ART OF THE MIDDLE AGES
}

\author{
Daniel Russo \\ Department d'Histoire de l'Art et d'Archeology, \\ Université de Bourgogne. Institut Universitaire de France
}

\begin{abstract}
This article aims to contextualize the main currents in the interpretation of medieval images, underlining the appearance of an original matrix of thought, thinking through art, between 1950 and 2000. At the heart of this new épistémè, the concept of imagepresence is put forward and it is discussed on the basis of three examples dated between the year 1000 and c. 1450 and through an interdisciplinary dialogue with social anthropology and the philosophy of science.
\end{abstract}

Keywords

Image $\bullet$ visual presence $\bullet$ intellectual history.

\section{Contact:}

Université de Bourgogne

Département d'Histoire de l'art et d'Archéologie

2 Bd Gabriel - 21000 - Dijon - France

E-mail: daniel.russo@u-bourgogne.fr

* Translation by Maria Cristina Correia Leandro Pereira. 
Para responder ao pedido que me foi feito pelos dois coordenadores do workshop "A imagem medieval: história e teoria"1 - Maria Cristina Pereira e Eduardo Henrik Aubert -, realizado na Universidade de São Paulo, indicarei inicialmente as principais fases ao longo das quais, pouco a pouco, a partir do final dos anos 1970, sobretudo na França, constituiu-se e depois se afirmou um campo de estudos novo em torno das imagens, primeiro nas sociedades antigas e, em seguida, nas medievais. ${ }^{2}$ Foi durante esses anos que o conceito de imagem foi trabalhado a partir das problemáticas advindas, por um lado, dos trabalhos de Jean-Pierre Vernant (1914-2007) e, por outro, da psicologia, em função das pesquisas realizadas por Ignace Meyerson (1885-1983). Nesse mesmo período, foi proposto, no seio do Laboratório de Antropologia Histórica da EHESS, em Paris, o conceito de "imagem-objeto" que, desde então, tem sido incessantemente aprofundado, para o período medieval, por Jacques Le Goff, Jean-Claude Schmitt, Jean-Claude Bonne, Michel Pastoureau, Jérôme Baschet e toda sua equipe. Buscava-se, a partir de abordagens globais, particularizar e, em seguida, integrar a noção de imagem às práticas visuais de uma dada cultura em um momento da história $^{3}$ e, de maneira mais ampla, no campo das ciências humanas e sociais. Por volta de meados dos anos 1990, vinda dos países anglo-saxões e repensada a partir da leitura de filósofos franceses (Michel Foucault, 1926-1984, Jacques Derrida, 1930-2004), foi introduzida a "virada icônica" (iconic turn) e, com esse movimento, o conceito de afirmação de sentido ligado à imagem, retomando por vezes a percepção quase fenomenológica da substância e de seus efeitos. No

1 WIRTH, Jean. L'image médiévale. Naissance et développements. Paris: Méridiens Klinsieck, 1989, que é a primeira ocorrência da expressão autônoma "imagem medieval" no título de uma obra em francês.

2 Ver, entre outros: VERNANT, Jean-Pierre. Image et apparence dans la théorie platonicienne de la Mimèsis. Journal de Psychologie, v. 2, abril-junho, 1975, retomado como: Idem. Naissance d'images. In: Idem. Religions, histoires, raisons. Paris: La Découverte, 1979; Idem. CEuvres. Religions, rationalités, politique, I. Paris: Seuil, 2007, em part., p. 1.728-1.751. Ademais, lembro também que, na mesma época, no final dos anos 1970 e início dos anos 1980, era promovida, nas edições Maspero/La Découverte, a coleção Images à l'appui, sob a direção de Pierre VidalNaquet, na qual eram lançadas, alternadamente, obras sobre imagens antigas e medievais; para estas últimas, tratavam-se de teses de doutorado defendidas por estudiosos formados na École Française de Rome.

3 SCHMITT, Jean-Claude; BASCHET, Jérôme (dir). L'image. Fonctions et usages des images dans l'Occident médiéval. Paris: Le Léopard d'Or, 1996; SCHMITT, Jean-Claude; SANSTERRE, Jean-Michel (dir.). Pratiques des images dans la société médiévale. Actes du Colloque international (Roma, Academia Bélgica, 19-20 juin 1998). Bulletin de l'Institut Historique Belge de Rome 69, 1999. Para situar historicamente um momento "pertinente" de imagens, BASCHET, Jérôme. La civilisation féodale. De l'an mil à la colonisation de l'Amérique. Paris: Aubier, 2004, em particular a segunda parte, cap. 6, p. 460-502 ("L'expansion occidentale des images"); ver também, Idem. L'iconographie médiévale. Paris: Gallimard/Folio, 2008. 
mundo norte-americano, os trabalhos conduzidos por Herbert L. Kessler são, incontestavelmente, o melhor desta corrente de interpretação, rica e múltipla, recolocada na evolução histórica das culturas e das sociedades da Idade Média, ${ }^{4}$ com ênfase na matéria, nas materialidades do trabalho artístico e no savoir-faire do artista que, a partir de então, eclipsa o artesão e o ultrapassa definitivamente ao longo das etapas de seu trabalho, opus. Na sequência dessa operação historiográfica, e de forma nova, são eliminados os obstáculos falsamente mantidos pela obstinação de se querer fazer corresponder textos às "imagens", que se tornam ao logo do tempo seus apêndices obrigatórios. Aqueles, no entanto, não são necessários, porque sem cessar as imagens ultrapassam os textos, ignoram-nos e tornam-se fontes de novas situações imaginadas para além da referência a uma relação com o mundo fundada exclusivamente na interpretação. ${ }^{5}$

Neste ensaio, revisito a historiografia a respeito dos principais aspectos do pensamento sobre as imagens na arte como pensamento pela arte e busco precisar o que seria o "conceito do conceito": o de "imagem-presença". ${ }^{6}$ Baseando-me em três exemplos que concernem, a meu ver, às três sequências primordiais do processo em curso, dos séculos IX/X até meados do século XV, inicialmente nos meios monásticos e em seguida nas sociedades urbanas, pretendo analisar:

- a presença dos signos gráficos no seio das culturas monásticas como traços vivos da presença do divino, no Manuscrito 1 conservado em Semur-en-

4 KESSLER, Herbert L. Seeing medieval art. Peterborough: Broadview Press, 2004, em part. cap. 1 e 2, p. 19-44, p. 45-64 ("Matter"; "Making"). Sobre a aplicação direta dessa corrente de interpretação às materialia da arte da Alta Idade Média, Idem. Spiritual seeing. Picturing God's invisibility in medieval art. Filadélfia: University of Pennsylvania Press, 2000 (para exemplos de séries, estudadas entre o período tardo-antigo e o ano mil).

5 KESSLER, Herbert L. Neither God nor man. Words, images, and the medieval anxiety about art. Freibourg-en-Brisgau/Berlim/Viena: Rombach, 2007, mostra como as imagens vão além dos textos, no tocante à tradição manuscrita dos versículos "Nec Deus est nec homo, praesens quam cernis imago,/Sed Deus est et homo quem sacra figurat imago" e o processo de imaginação à obra nas iluminuras dos fólios: ele mostra, assim, como, e sobretudo porque, o pensamento do artista é um pensamento pela arte. Sobre esse processo, ver: RUSSO, Daniel. Herbert L. Kessler: les jeux du texte et de l'image. La libération du visuel dans l'art médiéval. Revue de l'Art, 164, 2009 , p. 67-73. Sobre o extravasamento incessante dos textos pelas imagens, em uma tipologia que não seria mais fundada apenas no modelo da interpretação para dar conta do conjunto de nossas relações com os textos, com os objetos culturais e com o mundo, GUMBRECHT, Hans Ulrich. Éloge de la présence. Ce qui échappe à la signification. Trad. fr. Paris: Libella-Maren Sell, 2010, em part. p. 87-142 (“Au-delà de la signification”).

6 Sobre a pesquisa do conceito englobante, no campo filosófico, tomo a expressão de ROMANO, Claude. Au cour de la raison, la phénoménologie. Paris: Gallimard/Folio Essais, 2010, em part. cap. 9, p. 328-372 ("Le concept de concept"), a partir da análise do estatuto das essências na fenomenologia, em confrontação com outras abordagens filosóficas. 
Auxois, que pode ser datado por volta do ano mil e que me pareceu ser um bom ponto de partida para o estabelecimento de uma tradição ao mesmo tempo de pensamento e de olhar;

- a estrita hierarquização dos meios gráficos para a comunicação da forte presença de uma ausência, especialmente nas culturas urbanas e no seio das ordens mendicantes, particularmente dos dominicanos, dos anos 1260 até a grande composição em afresco na antiga sala capitular de Florença, no interior da igreja dominicana de Santa Maria Novella, por Andrea di Bonaiuto (1366-1367);

- a reintrodução de signos apenas “figurativos”, dessa vez, e não mais gráficos, na matéria da pintura, a partir do exemplo dos retábulos flamengos e, entre outros, do tríptico da Adoração dos magos (1455) pintado por Rogier van der Weyden (Tournai, c.1400-Bruxelas, 1464) para a igreja de Santa Colomba de Colônia: a ausência figurada descreve uma presença espacializada à escala do painel inteiro, estabelecendo relações visuais com a mesa do altar.

Concluirei com algumas considerações a respeito das relações inerentes à arte, obra ou objeto, voltadas para a filosofia e a teologia, na Idade Média, mas também voltadas para as ciências, em particular as ciências naturais, em plena interdisciplinaridade consciente das questões propostas na qualidade de questões pendentes.

\section{0 pensamento pela arte}

Tomando distância em relação ao discurso comum da crítica sobre arte, feito de uma mescla de descrição fenomenológica - a experiência da obra! - e de edificação sentenciosa seguindo o modismo da hora - o elogio da resistência ou da hibridação, a aceitação de sentido ou da alteridade -, tento distinguir, através das práticas e dos discursos, novos objetos, novas abordagens, novos regimes, de acordo com uma problemática familiar à arte contemporânea, a da série, mas restringindo-a - já que os objetos e operações são solidários - para que ela não coincida apenas, como instava há pouco tempo Patrice Maniglier, com a questão da "aura" da obra de arte ou com a questão da conceitualização, mas para que ela se abra para a "identidade material da coisa e para que ela coloque em evidência uma identidade que advenha da multiplicidade de abordagens (no sentido rigoro- 
samente espacial) das quais ela pode ser objeto". ${ }^{7}$ Nesse caminho, que se afasta daquele da "performance" das imagens e dos discursos, ${ }^{8}$ conceito difundido hoje um pouco por todo lado e, sem dúvida, de forma demasiado rápida, chamarei a atenção para os objetos, porque eles estabelecem práticas que revelam sempre alguma coisa dos processos próprios ao agir artístico e ao tipo de circulação que este autoriza entre os diferentes regimes de saber e da experiência, e isso melhor que qualquer outra prática estudada pelas ciências humanas e sociais. ${ }^{9}$ É também por essas vias que pode advir a junção entre arte e teoria e, em particular, a estética, no espaço-tempo de suas sucessivas atualizações. ${ }^{10}$

MANIGLIER, Patrice. "Dessine-moi un éléphant". Pédagogie et recherche en art. Critique, 759760, agosto-setembro, 2010, p. 758-771, em part. p. 769-770. Ver a compilação de textos reunidos por ALLOA, Emmanuel. Penser l'image. Dijon: Les presses du réel, 2010. Em particular, "Perceptions", sobre essa problemática declinada em quatro argumentos principais: 1) o lugar das imagens; 2) as perspectivas históricas; 3) a vida das imagens; 4) as restituições. ALLOA, Emmanuel. Entre transparence et opacité - ce que l'image donne à penser. Introduction. In: Idem. Penser l'image, op. cit., p. 7-23. Por abordagem entendida no sentido espacial do termo, "rigorosamente", Patrice Maniglier subentende toda "uma abordagem local da própria noção de espaço", articulada, tanto que possível, com a percepção de conjunto, ao final de uma "renegociação" com o nível global. Idem. "Dessine-moi un éléphant". Pédagogie et recherche en art, art. cit., p. 762-763. Para uma reflexão em estética, DURING, Élie. Faux raccords. La coexistence des images. Arles: Actes sud/Villa Arson, 2010, em part. o capítulo "Constructions", em part. p. 24-25, para a discussão de caso da conexão espaço-temporal do tipo "de junção de duas superfícies perpendiculares" [a partir de JAMES, William. A pluralistic universe (Nova Iorque, 1909), reed. Lincoln/Londres: Bison Books/University of Nebraska Press, 1996]; para uma posição dos problemas em filosofia e história das ciências, RABOUIN, David. Vivre ici. Spinoza, éthique locale. Paris: PUF, 2010.

8 GELL, Alfred (1941-1997). L'art et ses agents, une théorie anthropologique (Oxford, [1998], Oxford University Press), trad. fr. Dijon: Les presses du réel, 2009. Para uma discussão sobre o conceito de "agenciamento", agency, e seu modo operatório em rede de arte, nexus, transposto em termos históricos, mais ou menos adequados, DIERKENS, Alain; BARTHOLEYNS, Gil; GOLSENNE, Thomas (ed.). La performance des images. Bruxelas: Université Libre de Bruxelles, 2009.

9 Michel de Certeau (1925-1986) teria escrito que se tratava de uma "operação historiográfica"; ver o número da Revue d'histoire des sciences humaines 23, 2010, preparado por Tiago Pires Marques; sobre as noções de "saber" e de experiência, do ponto de vista da antropologia social dos objetos, HOUDART, Sophie; THIERY, Olivier (ed.). Humains non humains. Comment repeupler les sciences sociales. Paris: La Découverte, 2011, em part. parte V, p. 257-320 ("Le bouleversement en art"). Para uma primeira pesquisa sobre o objeto e a coisa, res, MAGNANI, Eliana; RUSSO, Daniel. Histoire de l'art et anthropologie, 3. Exégèse textuelle, exégèse visuelle. Autour du processus de la chose, res, dans le haut Moyen Âge. Bulletin du C.E.M. d'Auxerre, 13, 2009, p. 103-120 [http://cem.revues.org/index11035.html]

${ }^{10}$ De acordo com DURING, Élie; JEANPIERRE, Laurent. Introduction. À quoi pense l'art contemporain?. Critique, 759-760, agosto-setembro, 2010, tratar-se-ia de um "enlaçamento entre a arte e a teoria”; ver suas observações, em particular na p. 646: “(...) Não se trata de ser mais sábio ou mais esperto, nem pensar em coisas inauditas, mas de buscar conexões: o real da arte - aquilo pelo qual ela provoca a pensar - está na invenção desses engates”. Reportar-se também a DURING, Elie. Faux raccords. La coexistence des images, op. cit., em part. p. 11-25; III, p. 153-205 ("Introduction"; "Connexions"). 
Situarei, pois, as grandes correntes de leitura das imagens que, nos últimos anos, sucederam-se, no tocante às orientações intelectuais e às questões epistemológicas dos momentos de sua elaboração. No fundo, na trama geral das questões postas à imagem ou, mais exatamente, àquilo que faz imagem, dois pontos fortes surgem quase ao mesmo tempo e eu os resumirei em duas interrogações, tomadas a Emmanuel Alloa: “O que é a imagem?" e "Quando há imagem?". ${ }^{11}$

A fim de melhor formular a primeira interrogação e tentar trazer alguns elementos de resposta, precisarei que, por volta dos anos 1960/1980, tanto na Europa como em outras partes, preocupou-se com o que é a imagem sem, no entanto, defini-la precisamente, nem através de sua etimologia nem do campo semântico no qual ela se insere, circunscrevendo-a de fora, a partir do exterior do que a constitui materialmente. Assim, a imagem pode ser percebida em um conjunto de relações complexas tramadas entre elas, no seio de dispositivos e práticas que lhe permitem produzir efeitos: portanto, "falar" e "agir", "suscitar" e "gerar", mesmo "rejeitar" ou, a fortiori, "censurar". Um dos primeiros marcos decisivos nesse sentido é o interesse direcionado às artes da memória; ${ }^{12}$ o segundo marco, não menos importante, foi a introdução da eficácia das imagens nos campos da história política e da história social, a partir da definição da infâmia penal e da emergência de uma categoria particular de imagens - imagens políticas -, a das "imagens infamantes" ${ }^{13}$ De resto, e isso é uma contribuição interessante da reflexão então em curso sobre as imagens "que agem", é introduzida a noção de espectador e, com ela, a consideração de suas intenções como agente, que propõe, e como ator, que desempenha um papel no seio de um dispositivo mais vasto, ordenado a fim de produzir, pro-ducere, uma interpretação e de impô-la aos olhares em um dado momento: o conceito foucaultiano de dispositivo retoma e afina aquele outro, anterior, de posicionamento, fechando, ao mesmo tempo, qualquer abertura a outras possibilidades de ver e de compreender. ${ }^{14}$ De toda forma, a imagem só adquire seu acabamento a partir do exterior.

${ }_{11}$ ALLOA, Emmanuel. Changer de sens. Quelques effets du "tournant iconique". Critique, 759760, agosto-setembro, 2010, p. 647-658.

${ }_{12}$ A redescoberta das artes memoriae e, na mesma cronologia, das obras de Frances A. Yates (18991981) e de Paolo Rossi, é, nesse sentido, de grande interesse, porque a imagem age e fala, como no palco de um teatro da memória, e isso desde a Antiguidade clássica. YATES, Frances A. L'art de la mémoire (Londres, [1966]). Trad. fr. Daniel Arasse. Paris: Gallimard, 1975; ROSSI, Paolo. Clavis universalis, logique combinatoire, arts de la mémoire. Trad. fr. Grenoble: Jérôme Million, 1993. Síntese em: BOLZONI, Lina; CORSI, Pietro (ed.). La cultura della memoria. Bolonha: Il Mulino, 1992.

${ }^{13}$ Ver o belo livro de ORTALLI, Gherardo. La peinture infamante du XIIIe au XVIe siècle. Roma, [1979]). Trad. fr. Paris: Gérard Monfort, 1994.

${ }^{14}$ Sobre o conceito de dispositivo na filosofia de Michel Foucault, AGAMBEN, Giorgio. Qu'est-ce 
Seguindo outras vias, isso também ocorre no campo dos visual studies que, em alguns pontos, acabam por coincidir com um certo número de contribuições da semiótica das artes visuais, desenvolvida na França a partir dos anos 1960, e cujo postulado seria, no fundo, que a imagem resulta de uma composição cujo código pode permanecer invisível, mas que não é menos presente e que deve ser objeto de decifração: ao mesmo tempo em que a imagem é lida, isto é, decifrada, ela se constrói e cria sentido, como na fenomenologia husserliana [Edmund Husserl (1859-1938)], em que o que é "visível” não é dado, mas é sempre reconstruído. ${ }^{15}$ Nos anos 1990, e quase no mesmo momento, sem relações entre eles, Gottfried Boehm e William J. Thomas Mitchell, um na Alemanha e o outro nos Estados Unidos, forjaram as expressões "virada icônica' e "virada pictórica", iconic turn e pictorial turn, o primeiro se questionando "O que é a imagem?", e o segundo refletindo sobre as "representações" verbais e visuais entrecruzadas. ${ }^{16} \mathrm{Na}$ sequência de Gottfried Boehm, Hans Belting, na corrente da Bildanthropologie ("antropologia da imagem"), e Horst Bredekamp, na da Bildwissenschaft ("ciência da imagem"), viram aí meios úteis para institucionalizar a independência da imagem ou do quadro: na antropologia das imagens, Belting as situou como intermediários entre a vida e a morte, mediações indispensáveis à "presença do defunto" em sua ausência; na ciência da imagem, Bredekamp

qu'un dispositif? (2006). Trad. fr. Paris: Payot/Rivages, 2007; e Idem. Signatura rerum. Sur la méthode. (2007). trad. fr. Paris: Vrin, 2008. Para uma tentativa de aplicação à imagem visual em sua articulação com o textual, RUSSO, Daniel. Des lettres sur l'image dans l'art du Moyen Âge. Pour une nouvelle articulation du textuel et du visuel. In: HECK, Christian (ed.). Qu'est-ce que nommer? L'image légendée entre monde monastique et pensée scolastique. Turnhout: Brepols, 2010, p. 127-144, em part. p. 127-129 (“Un dispositif: nommer”); sobre a transposição para o palco do teatro e sobre a noção de "tela de representação", LOJKINE, Stéphane. La scène de roman. Paris: Armand Colin, 2002; e Idem. Image et subversion. Nîmes: Jacqueline Chambon, 2005.

${ }^{15}$ HUSSERL, Edmund. Idées directrices pour une phénoménologie (1913-1915). Trad. fr. Paris: Tel/Gallimard, 1985. Ver também, para a França, MERLEAU-PONTY, Maurice (1908-1961). Signes. Paris: Gallimard, 1960, em part. I e II ("Le langage indirect et les voix du silence"; "Sur la phénoménologie du langage”, p. 63-135; p. 136-158).

${ }^{16}$ BOEHM, Gottfried. Die Wiederkehr der Bilder. In: Idem. Was ist ein bild?. Munique: Wilhelm Fink, 1994, p. 11-38, sobre a presença da imagem e seu estatuto de objeto dotado de vida própria; MITCHELL, William J. Thomas. The pictorial turn. Picture theory. Essays on verbal and visual representation. Chicago: The University of Chicago Press, 1994, em part. p. 11-34; Idem. What do pictures want? The lives and loves of images. Chicago: The University of Chicago Press, 2005, em part. p. 111-196, (II, "Objects"), sobre as imagens que "vivem vidas" que só são em parte controladas por aquelas e aqueles que as produziram, e p. 197-356 (III, "Media"), sobre sua existência por "posteridade midial", que lhes permite se proliferar e se reproduzir. Sobre essas duas abordagens concomitantes, mas em nada ligadas uma a outra, e para uma recontextualização da história intelectual desses anos 1990, MOXEY, Keith. Les études visuelles et le tournant iconique. Intermédialités, 11, 2008, p. 149-168, que analisa as grandes correntes na constituição e na análise do visual: a Bildwissenschaft, a Bildanthropologie, os "estudos visuais" (p. 164). 
situou a imagem no seio de um dispositivo fruto de um debate ao mesmo tempo técnico e filosófico que tomou por uma forma de "pensamento visual": os desenhos e os esboços de Charles Darwin (1809-1882) de uma barreira de corais são os equivalentes visuais da ideia de uma evolução não linear das espécies vivas. ${ }^{17}$ Ambos se afastaram dos image studies à moda americana, dos "estudos visuais", nos quais a imagem é estudada como um prisma que permite o acesso às relações de poder e aos jogos no interior de uma sociedade para analisar assim os diferentes fatores de semantização que a atravessam, ficando concentrados na força de um potencial ideológico. ${ }^{18}$

Nos dois casos, no entanto, a "grande transformação" da imagem e de todo processo que ela implica não ocorre, sendo reduzida a um simples "processo" de documentação do estado das coisas. E a oposição entre a imagem como signo natural e a imagem como cristalização de fatores culturais é menos profunda do que parece à primeira vista: a imagem indício de uma presença e a imagem símbolo de uma representação parecem ser, no fundo, bastante próximas, para não dizer demasiado próximas. Seguindo as duas vias, de fato, a imagem permanece uma "janela aberta" permitindo ter acesso ao que há atrás dela, como no tempo de Leone Battista Alberti (Gênova, 1404-Roma, 1472) e de seu tratado De Pictura, della pittura (1434).${ }^{19}$ Essas duas possibilidades de leitura de imagens, ao mesmo tempo em que se inscrevem contra ela, herdam muito da aporia inerente à iconologia de Erwin Panofsky (1892-1968) e ao "textualismo irredutível” que motivava toda sua pesquisa, consagrando em definitivo a subordinação da imagem ao texto e, portanto, sua forte "desvalorização epistemológica" em relação a ele. ${ }^{20}$ Em suma, isso marca um excesso de semiotização que só considera o visível enquanto ele é legível.

${ }^{17}$ BELTING, Hans. Pour une anthropologie des images (Munich, 2002). Paris: Gallimard, 2004 ("Le temps des images"); BREDEKAMP, Horst. Les coraux de Darwin. Premiers modèles de l'évolution et tradition de l'histoire naturelle (Berlim, 2003). Dijon: Les presses du réel, 2008, em part. p. 40 ss.

${ }^{18}$ MIRZOEFF, Nicolas. Introduction to visual culture. Londres: Routledge, 1999, sobre a situação na história dessas problemáticas.

${ }^{19}$ Sobre esse texto, ver a tradução recente GOLSENNE, Thomas; PRÉVOST, Bertrand; HERSANT, Yves. La peinture, Leone Battista Alberti. Paris: Seuil, 2004; sobre Leone Battista Alberti, PAOLI, Michel. L'idée de nature chez Leone Battista Alberti (1404-1472). Paris: Honoré Champion, 1999; e Idem; CHOAY, Françoise (ed.). Alberti, humaniste et architecte. Paris: Musée du Louvre/ École nationale supérieure des Beaux-Arts, 2006. Sobre o público de Alberti, seus gostos, suas expectativas, FURLAN, Francesco. Studia Albertiana. Lectures et lecteurs de L. B. Alberti. Paris/ Turin: J. Vrin/Nino Aragno, 2003.

${ }^{20}$ Tomo as citações de ALLOA, Emmanuel. La résistance du sensible. Paris: Kimé, 2008; e Idem. De l'idéologie. Heidegger et l'archéologie d'une science oubliée. In: Idem. Penser l'image, op. cit., p. 117-143. 
E quanto à segunda interrogação? Quando há imagem (image) e mesmo um elemento imagético (de l'image)?

Entre o fim dos anos 1980 e os anos 1990, em contraposição, farei referência a uma outra corrente de estudos que não deixou de ressuscitar e de evocar a ideia de presença, tanto para voltar as preocupações em direção a uma concepção religiosa, como por exemplo, George Steiner, ${ }^{21}$ quanto para reafirmar a força de um paradigma que se gostaria que substituísse o da semiótica: o paradigma da presença no mundo, ou da anti presença, a presença estando situada além de todo horizonte visível e compreensível. O pensamento de Gianni Vattimo é, sem dúvida alguma, exemplar dessa orientação, ao colocar o "presente" para além de toda formulação, ${ }^{22}$ e que é um conceito retomado e discutido por Hans Ulrich Gumbrecht no sentido da destruição, no seio do que ele chama de $h u$ manities, do forte "tabu" levantado "contra todas as linguagens potencialmente 'não-hermenêuticas', isto é, 'substancialistas'" ${ }^{23}$ Do ponto de vista da imagem, substitui-se a ideia de representação, fundada na concepção transitiva da imagem, pelo conceito de presença, que remete, por sua vez, a uma concepção intransitiva, imanente, liberada de qualquer submissão ao que quer que seja, estando no lugar apenas dela mesma. Os prolongamentos são fáceis de encontrar e de citar na arte contemporânea, das cores negras pastosas e espessas de Pierre Soulages (1919-) às reflexões de Frank Stella (1936-) sobre o "antirrepresentacionalismo" da arte

${ }^{21}$ STEINER, George (1929-). Martin Heidegger (1978). Paris: Albin Michel, 1981; Idem. Les Antigones (1984). Paris: Gallimard, 1986; Idem. Le sens du sens. Paris: J. Vrin, 1988; Idem. Réelles présences. Les arts du sens. Paris: Gallimard, 1991. A abordagem se aproxima, em certos aspectos, da de René Girard (1923-), em torno de seu tema de predileção, "perspectivas humanas e perspectivas cristãs", presente em todas suas obras e, em particular, com VATTIMO, Gianni (1936-). Christianisme et modernité. Paris: Flammarion Champs, 2009; e Idem. La conversion de l'art. Paris: Carnets Noirs, 2010). Ver também ECO, Umberto (1932-). De l'arbre au labyrinthe. Études historiques sur le signe et l'interprétation (Milan, [2003], Bompiani). Paris: Grasset, 2010, em part. cap. 2 e 3, p. 121-198, ("La métaphore comme connaissance: infortune d'Aristote au Moyen Âge", "De la métaphore à l'analogia entis").

${ }^{22}$ VATTIMO, Gianni. Au-delà de l'interprétation (Rome/Bari, 1994). Bruxelas: De Boeck, 1997, em part. p. 33: “(...) A leitura que proponho da história do ser [é a da] história de um 'longo adeus', de um enfraquecimento interminável do Ser. Se a metafísica é ultrapassada, é somente para se lembrar do esquecimento, nunca para trazer o Ser à presença, ainda que fosse como um termo sempre presente para além de toda formulação (...)".

${ }^{23}$ GUMBRECHT, Hans Ulrich. Éloge de la présence, op. cit., em part. p. 93; e acrescentar, na sequência: “(...) Nós entramos em acordo, Vattimo e eu, sobre o que Heidegger entendia por 'história do Ser', mas nós reagimos, ele e eu, de maneira totalmente diferente frente a esse conceito. Esforço-me para opor a substancialidade do Ser à universalidade pretendida da interpretação infinita, enquanto que Vattimo busca fazer desaparecer o Ser (o desejo de ser) por trás de uma reiteração infinita de interpretações. (...)". 
minimalista, para sublinhar que a opacidade da matéria resiste à "semiose". ${ }^{24}$ É aqui que se individualiza a presença da obra, que é um trabalho aberto ao mundo, porque ela é antes de tudo presença da obra em - e sobre - si mesma, em sua não-repetição e em toda sua "singularidade de acontecimento". ${ }^{25}$ Após o pensamento alegórico da imagem, que a considerava como dizendo outra coisa que ela mesma, surge o pensamento da imagem sobre ela mesma, em suma, um pensamento tautológico, no bom sentido da palavra.

É surpreendente assistir, recentemente, ao retorno com força da ideia de presença tanto na história da filosofia como na estética. É certo que as releituras sucessivas de Henri Bergson (1859-1941) e de Maurice Merleau-Ponty não são alheias a isso, assim como o relativo esquecimento de algumas tomadas de posição, sem dúvida muito forçadas, como a da desconstrução. A nova tendência marcaria então uma corrente um tanto contrarreformadora, talvez também bem característica de seu tempo. Ao Louis Marin (1931-1992) de Détruire la peinture [Paris, (1977), Galilée], prefere-se, com algumas notáveis exceções, o autor em seus trabalhos sobre a presença do signo através do processo da representação ou sobre a gramática de Port-Royal-des-Champs e a pintura de Philippe de Champaigne (Bruxelas, 1602-Paris, 1674) ${ }^{26} \mathrm{O}$ questionamento foi ainda mais aprofundado a partir da noção da presença real, ferramenta cômoda para produzir laços com a liturgia e a história, a espacialização na Europa feudal e as grandes fases da evolução social. ${ }^{27} \mathrm{O}$ conceito de presença persegue todos

${ }^{24}$ Ver a retrospectiva sobre Pierre Soulages, Centre Georges Pompidou (14 outubro 2009-8 março 2010), catálogo Soulages. Paris: Centre Georges Pompidou, 2009; sobre Frank Stella, ALLOA, Emmanuel. Changer de sens. Quelques effets du tournant iconique, art. cit., em part. p. 651, para a citação de sua fórmula: "'What you see is what you see'. Nem mais e nem menos. (...)".

${ }^{25}$ Uso a expressão de ALLOA, Emmanuel Changer de sens. Quelques effets du tournant iconique, art. cit., p. 651 n. 8, que cita MERSCH, Dieter. Was sich zeigt. Materialität, Präsenz, Ereignis. Munique: Wilhelm Fink, 2002.

${ }^{26}$ Ver suas obras fundamentais, algumas delas reeditadas: MARIN, Louis. De la représentation. Paris: Seuil, 1993; Idem. Philippe de Champaigne ou la présence cachée. Paris: Hazan, 1995; Idem. Pascal et Port-Royal. Paris: PUF, 1997; Idem. Opacité de la peinture. Essais sur la représentation au Quattrocento (Uscher, 1989). Paris: EHESS, 2006; rica discussão em: POUSSIN, Frédéric; ROBIC, Sylvie (ed.). Signes, histoires, fictions. Autour de Louis Marin. Paris: EHESS, 2004.

${ }^{27}$ BELTING, Hans. La vraie image. Croire aux images? (Munique, [2004]). Paris: Gallimard, 2007, em part. p. 201-208 (“La querelle de la Cène: présence ou signe ?”), para uma formulação útil; ver igualmente ALLOA, Emmanuel. Changer de sens. Quelques effets du tournant iconique, art. cit., p. 652. Discussão dessa problemática e de sua incidência no campo icônico, em Roma e no resto do Ocidente latino na Idade Média, WOLF, Gerhard P. 'Salus Populi Romani': Studien zur Geschichte des römischen Kultbildes im Mittelalter. Heidelberg: VCH, 1990; RUSSO, Daniel. Le Christ entre Dieu et homme dans l'art du Moyen Âge en Occident (IXe-XVe siècles). Essai d'interprétation iconographique. In: LE GOFF, Jacques; LOBRICHON, Guy (ed.). Le Moyen $\hat{A}$ ge aujourd'hui. Trois regards contemporains sur le Moyen Âge: histoire, théologie, cinéma. 
os discursos, mesmo onde não se esperaria, nas interpretações do significado: por exemplo, e entre outros, William J. Thomas Mitchell lembra, com insistência, que, na experiência quotidiana das imagens, mesmo contemporâneas, as pulsões idólatras, fetichistas, "totemizantes" parecem irrepreensíveis, tecendo relações em direção à antropologia social e ao conceito de figuração (sobre o qual retornarei na terceira e última articulação do ensaio).$^{28}$ Antes dessas observações, acrescentarei as de Jean-Paul Sartre (1905-1980) e de Roland Barthes (1915-1980). O primeiro, em L'imaginaire, propõe que a imagem permaneça intimamente ligada à morte, porque ela supõe o trespasse de seu referente e porque ela apresenta, então, aquilo que está "ausente na percepção", ${ }^{29}$ abrindo o caminho, por conseguinte, ao rico desenvolvimento do par "presente/ausente", paradigmático em sua própria dialética. O segundo, em sua La chambre claire, sublinha como as fotografias escolhidas desenhavam, a cada vez, "uma presença, mas em suspensão", precisando o estatuto de um corpo "em imagem", ali, naquele lugar mesmo, e no momento em que o corpo é subtraído aos presentes. ${ }^{30}$ O par "presente/ausente" domina, pois, toda uma tradição analítica que recebeu suas melhores contribuições de pesquisadores como Hubert Damisch (1928-) e Daniel Arasse (1944-2003), cujo estudo sobre a Anunciação na arte italiana é exemplar em muito aspectos. ${ }^{31}$

Paris: Le Léopard d'Or, 1998, p. 247-279; KESSLER, Herbert L. Spiritual seeing. Picturing God's invisibility in medieval art, op. cit., em part. p. 149-189. Para o Império bizantino, há belas análises em PEERS, Glenn. Subtle bodies. Representing angels in Byzantium. Berkeley/ Los Angeles/Londres: University of California Press, 2001.

${ }^{28}$ MITCHELL, William J. Thomas. Iconologie. Image, texte, idéologie (Chicago, [1986]). Paris: Les prairies ordinaires, 2009, em part. p. 246-313 (III parte, cap. 6, "La rhétorique de l'iconoclasme. Marxisme, idéologie et fétichisme") e p. 17-27 ("Préface" inédito da edição francesa). Sobre o conceito de "figuração", DESCOLA, Philippe. La fabrique des images. Visions du monde et formes de la représentation. Musée du Quai Branly (16 fevereiro 2010-11 julho 2011), catálogo de exposição. Paris: Somogy, 2010, em part. p. 11-19 ("Manières de voir, manières de figurer"); para a exposição de um "outro ponto de vista", não mais sobre o "corpo figurado", mas sobre o "corpo em relação": TAYLOR, Anne-Christine; VIVEIROS DE CASTRO, Eduardo. Un corps fait de regards. Amazonie. In: BRETON, Stéphane (ed.). Qu'est-ce qu'un corps?. Musée du Quai Branly (23 junho 2006-25 novembro 2007). Paris: Flammarion/Musée Branly, 2006, p. 148-199.

${ }^{29}$ SARTRE, Jean-Paul. L'imaginaire. Paris: Gallimard, 1940, de onde retiro expressões como: "a consciência imaginante repleta de seu saber descritivo", ou ainda, "o objeto da imagem mental".

${ }^{30}$ BARTHES, Roland. La chambre claire. Paris: Seuil, 1980; ALLOA, Emmanuel. Changer de sens. Quelques effets du 'tournant iconique', art. cit., p. 652, comenta que “(...) Face à fotografia de Lewis Paine, condenado a morte, Barthes descreve a experiência de uma estranha duplicidade, consistindo em ver o assassino vivo e ao mesmo tempo sabê-lo já morto, a copresença na imagem de um já foi e de um será que já aconteceu (...)". Sobre a "copresença na imagem”, DURING, Élie. Faux raccords, la coexistence des images, op. cit., igualmente sobre essa mesma linha de problemática.

${ }^{31}$ DAMISCH, Hubert. Théorie du nuage, de Giotto à Cézanne. Pour une histoire de la peinture. 
Aprofundando-me mais, aproximaria o retorno à presença, no seio das ciências humanas e sociais, da história de sua formação como campo interdisciplinar, com uma alternância de períodos com paradigmas "duros" e outros com paradigmas "brandos", como se se tratasse, para elas, de reagir a seu "ato de nascimento" como disciplinas baseadas na exclusão de todas as dimensões epistemológicas para além da percepção e do referente. ${ }^{32}$ Tomando certo recuo, voltarei ao final dos anos 1950, nos estudos literários, na filosofia, na estética e nas "ciências históricas", para a abordagem branda do new criticism e a do imanentismo interpretativo que conheceram então um grande sucesso, logo seguido do desenvolvimento da hermenêutica. Isso poderia ser compreendido como um conjunto de reações pensadas a partir de diferentes episódios de incremento do viés ideológico e político em diferentes países. Depois, e como uma espécie de contragolpe, no final daqueles mesmos anos, surgiram ondas simultâneas de paradigmas mais duros, entre os quais o estruturalismo, a linguística estrutural, o "formalismo russo", introduzidos na literatura e, em seguida, nas ciências humanas e nas artes. Segundo os modelos de análise experimentados em outros campos disciplinares, a ambição era de ultrapassar a subjetividade de toda interpretação e de se juntar, participando dela, à admiração pelas abordagens sociológicas e pela história da recepção, sobretudo nos estudos literários. Por volta dos anos 1970/1980, no entanto, a pesquisa pós-moderna, sob a influência da desconstrução e também do novo historicismo, retomou certo número de postulados anteriormente emitidos, qualificando, com facilidade, de ingênuo qualquer desejo de rigor teórico e metodológico. Ademais, a desconstrução e o novo historicismo começaram por uma crítica com argumentos do estruturalismo - paradigma "duro" - encontrando grande eco nos Estados Unidos, entre a geração dos especialistas da literatura formados no new criticism, a "nova crítica", e em alguns desses princípios. Foi esse o meio de acolhida das teorias de Derrida e de Foucault. A alternância entre

Paris: Seuil, 1972; Idem. Fenêtre jaune cadmium ou les dessous de la peinture. Paris: Seuil, 1984; Idem. Le jugement de Pâris. Iconologie analytique 1. Paris: Flammarion, 1992; ARASSE, Daniel. L'Annonciation italienne. Une histoire de perspective. Paris: Hazan, 1996; Idem. Le sujet dans le tableau. Essais d'iconographie analytique. Paris: Flammarion, 1997; Idem. On n'y voit rien. Descriptions. Paris: Gallimard, 2000.

32 Sobre a formação da epistemologia como campo científico de estudo, suas questões, seus objetos, HEMPEL, Carl. Éléments d'épistémologie. Paris: Armand Colin, 2004, em part. cap. 2 e 7, p. 5-27, p. 133-156 ("La recherche dans les sciences: invention et mise à l'épreuve des hypothèses", "La formation des concepts"). Para uma reflexão pertinente sobre a noção de campo epistemológico nas ciências humanas e sociais, a partir do exemplo brasileiro, ASFORA, Wanessa C.; AUBERT, Eduardo Henrik; CASTANHO, Gabriel C. G. L'histoire médiévale au Brésil. Structure d'un champ disciplinaire. In: MAGNANI, Eliana (dir). Le Moyen Âge vu d'ailleurs: voix croisées d'Amérique Latine et d'Europe. Dijon: EUD, 2010, p. 53-118. 
práticas duras e brandas no seio das ciências humanas e sociais pode dar conta, em certa medida, da corrente bastante favorável hoje ao conceito filosófico de presença, em suas diversas aplicações, inclusive na história da arte, no estudo das imagens e na arte contemporânea. ${ }^{33}$

Melhor circunstanciada que a precedente, essa fase de estudos levou a circunscrever as áreas de emergência da imagem. Ainda que ela tenha sustentado um movimento de compreensão da imagem naquilo que a faz existir - em sua "imageidade" -, a questão deve ser levantada para fechar esse breve apanhado de história intelectual por meio da imagem.

Uma vez ultrapassada a questão delicada da singularidade da imagem e do que a diferencia de outras formas de simbolização, depreende-se desta análise um sentido que qualificarei de presentativo, um sentido que se manifesta na própria textura da imagem, como em uma exibição de si mesma, graças ao suporte que a demonstra também. Assim, outra épistemè se esboça, caracterizada por "sua qualidade de sintoma". ${ }^{34}$ Isso porque o sintoma não é traço e supõe a presença de um corpo que se faz cenário ou tela apresentação, na dependência estreita de um olhar, ou mesmo de vários. Esse corpo-expositor é levado a se exceder para além de si mesmo em duas direções, que podem se reunir no final: uma, de exemplificação - o corpo sintoma não se parece com o que ele produz

${ }^{33}$ KITTLER, Friedrich. Discourse networks 1800/1900 (Berlim, 1985). Stanford: Stanford University Press, 1990 e a "Introduction" de David Wellbery para a edição americana. O autor propunha, ao mesmo tempo, uma explicação "psico-histórica" para a dominação do paradigma da interpretação no campo das humanities, e uma outra via de compreensão que ele condensava sob a expressão "psicofísica": por exemplo, saber em quê os avanços tecnológicos e suas aplicações nos novos meios de comunicação poderiam ou não dar origem a movimentos intelectuais. Um dos efeitos desse tipo de questionamento, de larga amplitude, foi o de se preocupar com as "materialidades da comunicação literária", integrando aí as descobertas mais recentes (por aquele então, por volta dos anos 1990) a respeito das medialidades. Para um bom exemplo dessas novas preocupações no que diz respeito ao que se chama de literatura medieval, ver ZUMTHOR, Paul. Introduction à la poésie orale. Paris: Seuil, 1983; Idem. La lettre et la voix: de la "littérature" médiévale. Paris: Seuil, 1987. Um outro exemplo, no estudo da arte contemporânea, em torno da manifestação organizada pelo Centre national d'art et de culture Georges-Pompidou sobre os Imateriais, ver o catálogo da exposição, Les Immatériaux: épreuves d'écriture. Paris: Centre national d'art et de culture Georges-Pompidou, 1985. Sobre a recepção de Derrida e de Foucault nos Estados Unidos, HOLSINGER, Bruce. The pre-modern condition. Medievalism and the making of theory. Chicago/Londres: University of Chicago Press, 2005.

${ }^{34}$ Uso os vocábulos épistémè e "sintoma" a partir de ALLOA, Emmanuel. Changer de sens. Quelques effets du 'tournant iconique', art. cit., en part. p. 653-654, na última parte da discussão sobre os efeitos possíveis de uma mudança de "sentido" a partir da "virada icônica"; Idem. De l'idéologie. Heidegger et l'archéologie d'une science oubliée. In: Idem. Penser l'image, op. cit., p. 117-145; COCCIA, Emmanuele. Physique du sensible. Penser l'image au Moyen Âge. In: ALLOA, Emmanuel, Penser l'image, op. cit., p. 95-117. 
ao olhar, ele exemplifica - e a outra, de espetáculo, em direção a um espectador que, olhando-o, dá-lhe sentido, porque ele faz sentido com o processo iniciado. Minhas observações se aproximam, aqui, dos estudos de Stéphane Lojkine sobre a tela e o cenário e também daqueles realizados por Georges Didi-Hubermann, por exemplo, em torno da Madona das sombras, pintada por Fra Angelico (Guido di Pietro, depois Fra Giovanni da Fiesole, dito - , província de Mugello, 1387-Roma, 1455), e hoje reinstalada no alto da escadaria que conduz ao primeiro andar do antigo dormitório do convento de São Marcos, transformado em museu de São Marcos. ${ }^{35}$ Uma outra via se abre, mais estreita certamente, mas ainda praticável, a da leitura da imagem em "traços" e em "esquemas", na encruzilhada da motricidade sensorial e da vida relacional, bem ancorada nos recônditos da vida psíquica, para reconstituir a construção do que vemos e enxergamos, tanto o visual quanto o material dos suportes de comunicação, incluindo o virtual. Serge Tisseron mostrou a riqueza dessa abordagem lidando com duas "operações psíquicas estreitamente tributárias das atividades motriciais-sensoriais primitivas", e talvez mesmo três: ele as denomina "esquemas de transformação", correspondendo às operações de união e desunião, e "esquemas de envolvimento", correspondendo à "inclusão de uma forma no interior de uma outra", acrescentando uma terceira, distinta da precedente, "de atração e separação", ou ainda, "de adução e abdução", todas elas estados psíquicos que encontram sua tradução nos equivalentes representativos, nas telas de exibição, de certa forma. ${ }^{36}$ Do mesmo modo, no registro inferior da Madona das sombras pintada por Fra Angelico, verdadeiros drippings de cores e de reticulações pictóricas, de um jorro poderoso, acompanham visualmente a história mostrada no compartimento principal do painel: se o estudo erudito, em

${ }^{35}$ LOJKINE, Stéphane. La scène de roman, op. cit., em part. cap. 1, sobre o teatro medieval e todo o jogo da paródia; DIDI-HUBERMANN, Georges. Fra Angelico. Figuration et dissemblance. Paris: Gallimard, 1987; Idem. Devant l'image: questions posées aux fins d'une histoire de l'art. Paris: Minuit, 1990; Idem. L'image ouverte. Paris: Gallimard, 2005.

${ }^{36}$ TISSERON, Serge. Psychanalyse de l'image. Des premiers traits au virtuel $(1995,1997)$. Paris: Fayard, 2010, em part. p. 9-10: “(...) Mas a tendência do funcionamento psíquico a figurá-los [os esquemas] tem duas consequências essenciais. Toda imagem psíquica ou material contém uma figuração de esquemas, mesmo bastante parcial, paralelamente aos desejos ligados às zonas erógenas que organizam as questões mais evidentes da imagem. Mas sobretudo - e essa é a argumentação essencial de Psychanalyse de l'image - esses esquemas são fortemente ligados à sua própria figuração para que se possa seguir sua evolução, e mesmo agir sobre eles, por intermédio das imagens" (grifos meus). E acrescenta, em seguida, “(...) A imagem psíquica não é somente o testemunho de um estado da psiquê. Ela é um fermento poderoso de suas mudanças. (...)". Alguns belos prolongamentos no estudo da literatura clássica e das emoções suscitadas pelos textos e imagens psíquicas em LE BRUN, Jacques. La jouissance et le trouble. Recherches sur la littérature chrétienne de l'âge classique. Genebra: Droz, 2004. 
história da arte, havia sempre pretendido não ver esse registro, não se trataria tampouco de fazer dele uma pintura modernista, libertada de toda relação com seu exterior, mas, ao contrário, de ver, e depois compreender, que a experiência da cor, sentida em sua espessura material de manchas e de não-formas, não se opõe ao textual e que ela o rearticula de maneira diversa. Os jatos coloridos, os pigmentos e as manchas multicoloridas não oferecem nada de abstrato: eles servem à pintura fazendo aquilo que a letra escrita não pode, encarnando, segundo Georges Didi-Hubermann, a dissimilitude do acontecimento que a história, no registro superior, definia na ordem da similitude: o advento de Jesus Cristo e o início da história cristã. Figurada e formando à vista um todo, surgindo na pintura e através dela, a imagem se afirma na simultaneidade dos dois registros, que são também dois regimes de temporalidades distintas, incompatíveis em essência, mas levados a coexistir nela, no seio de seu presente. ${ }^{37} \mathrm{~A}$ imagem avança uma apresentação (présentation) da mesma forma como, alhures, avançar-se-ia uma hipótese. $O$ pensamento pela arte é de fato, sob certas condições e exercícios, um pensamento da imagem.

\section{A imagem-presença}

Abordarei a análise desse conceito, depois de ter exposto suas bases teóricas e ao mesmo tempo historiográficas, a partir de três tópicos, situados no espaço medieval, entre sítios monásticos e comunas urbanas, escalonados no tempo, entre o ano mil e meados do século XV. Três exemplos retêm minha atenção por sua pertinência em relação a meu propósito: o manuscrito 1 da Biblioteca de Semuren-Auxois (Côte-d'Or); a série de realizações prestigiosas encomendadas pelos dominicanos, de 1260 a 1366/1367, no interior da Província Romana da ordem dominicana, no norte e no centro da península italiana; o exemplo do tríptico pintado por Rogier van der Weyden (Roger de la Pasture, Tournai, c.1399/1400Bruxelas,1464), mostrando a Adoração dos magos no compartimento principal (1455), para a igreja de Santa Colomba de Colônia.

O manuscrito 1, conservado na Biblioteca de Semur-en-Auxois, o mais antigo do fundo proveniente da abadia de Saint-Jean-de-Réome (Moustiers-Saint-Jean), deve ter sido realizado e pintado por volta do ano mil, antes de ter conhecido várias outras intervenções até o século $\mathrm{XV}$, e mesmo além. ${ }^{38} \mathrm{O}$ manuscrito, um

\footnotetext{
${ }^{37}$ DURING, Élie. Faux raccords, op. cit., sobre toda essa questão da coexistência e do que está implicado nisso, em part. p. 153-205, (III parte, "Connexions").

${ }^{38}$ Para o estudo em curso do manuscrito, AUBERT, Eduardo Henrick; MAGNANI, Eliana; RUSSO,
} 
libellus hagiográfico, advém desse gênero prestigioso de livros encomendados por comunidades monásticas poderosas, antes do século XII, e ricamente ilustrados para circunstâncias que marcaram especificamente a vida e os tempos fortes da memória do lugar. ${ }^{39}$ Em um ambiente monástico bastante denso, de reforma beneditina, o livro contendo passagens da vida do santo fundador, Jean de Réome, na parte que é datada por volta do ano mil, demonstra vários sintomas de sua vida no coração da liturgia e das práticas que o circundavam, dando conta assim de sua presença entre os monges. São materialidades da comunicação, textual e visual, dessa coisa, res, no centro da comunidade em um dado momento, inserida em uma trama cerrada de trocas, gestos, utilizações possíveis. Distinguirei sucessivamente três delas, insistindo na última que apresenta todo um discurso figurado entre texto e imagem.

Seguindo a ordem de emergência ao fio dos fólios do manuscrito e tendo em conta sua tipologia, a de um libellus de elevado preço, observo, inicialmente, a presença de iniciais rubricadas (cinco no total), coloridas de ocre vermelho. ${ }^{40}$ Isso corresponde a uma marcação que qualificarei de referencial de base na superfície dos fólios pintados e caligrafados com cuidado.

Observo, em seguida, e em outro registro da iluminura, ao longo da sequência das zonas de cores associadas umas às outras, a disposição de uma série de iniciais que delimitam, do interior, pelo traçado de seu contorno, um campo colorido: esse campo pode ser monocromático, obtido a partir de uma única tinta aplicada no interior da letra ${ }^{41}$ - uma camada um tanto fina de ouro-pigmento figurando a forma de um espaço de cor assim delimitado na superfície do pergaminho. Por vezes, e isso ocorre em dois fólios, ${ }^{42} \mathrm{o}$ ouro-pigmento só foi colocado por toques - ou pelo menos é essa a primeira impressão que se tem atualmente, pois

Daniel. Le manuscrit 1 de Semur-en-Auxois. Bucema - Bulletin du Centre d'études médiévales d'Auxerre, 14, 2010, p. 101-112 [http://cem.revues.org/index11561.html]; MAGNANI, Eliana; AUBERT, Eduardo Henrick ; RUSSO, Daniel. Écrire, chanter, voir, dans le monastère SaintJean-de-Réome autour de l'an mil. Sur le manuscrit 1 de Semur-en-Auxois. In: MAGNANI, Eliana; GASSE-GRANDJEAN, Marie-José (dir.). Productions, remplois, mises en registre: la pratique sociale de l'écrit à travers la documentation médiévale bourguignonne. Auxerre, Abbaye Saint-Germain, 24-25 setembro 2009; RUSSO, Daniel. Productions, remplois, mises en registre. Quelques réflexions. Bucema - Bulletin du Centre d'études médiévales d'Auxerre, 14, 2010, p. 157-167, [http://cem.revues.org/index11516.html].

${ }^{39}$ POULIN, Joseph-Claude. Les libelli dans l'édition hagiographique avant le XIIe siècle. In: HEINZELMANN, Martin (dir.). Livrets, collections et textes. Études sur la tradition hagiographique latine. Ostfildern: Thorbecke, 2006, p. 15-193.

${ }^{40}$ Os fólios 21r, 30r, 31v, 33v, 46r.

${ }^{41}$ Assim como nos fólios 3r, 4r, 5v, 11r, 12r, 13r, 17r, 18r e 37r.

${ }^{42}$ Os fólios $22 \mathrm{v}$ e $28 \mathrm{r}$. 
isso resulta, sem dúvida, da degradação química do pigmento utilizado e que é inerente à própria vida do livro pintado. Em contraposição, outras iniciais contêm um campo policromado com duas tintas, no mínimo, como no fólio $2 \mathrm{r}$ [figura 1, pág. 240], em que a letra inicial $d$-denique - mostra, em sua contraforma, a oposição entre quatro zonas figuradas em quadrados, a partir de um dispositivo simétrico entre três pigmentos: ouro-pigmento - utilizado duas vezes -, azul de azurita e ocre vermelho, distribuídos segundo o procedimento retórico da simetria. Trata-se de um pequeno "quadro" redondo encerrado no intervalo liberado pelos contornos do $d$ e parecendo nivelar-se ao olhar, a partir do fundo do velino, preparado, trabalhado e assim decorado. No fólio 35r [figura 2, pág. 240], a letrina F-Ferebatur interea per populos - delimita, entre seus dois braços, duas zonas coloridas de azul azurita, no alto, e de ouro-pigmento, embaixo, sendo separadas pelo traço em ocre vermelho que figura a barra horizontal do $F$. Esses espaços sobrepostos um ao outro se tornam quadrados de cores, quase de proporções iguais, desenhados na pasta dos pigmentos espalhados no fundo do pergaminho. Em sua parte superior, o $F$ é coberto de traços de azul sobre o ocre vermelho, ao passo que, na parte inferior, há marcas de ouro-pigmento: sem dúvida, rubricado em um primeiro momento, o $F$ recebeu em seguida a aplicação de dois pigmentos entre seus braços, servindo de suporte às figuras geométricas assim obtidas. Mais adiante no manuscrito, em sua segunda parte, onde as iniciais coloridas estão ausentes, no fólio 69r [figura 3, pág. 241], um Q-Quanto iam honore ac veneratione regum francorum - apresenta, na sua contraforma, quatro quadrados interrompidos pela circunferência, alternadamente nas cores ocre vermelho, empregado duas vezes, azul azurita e ouro-pigmento: parece surgir, do campo interior da inicial, um tapete de motivos de cores opostas, como se visto através de uma janela, em um procedimento de artista que não deixa de fazer pensar na arte contemporânea e em algumas de suas instalações mais modernas. ${ }^{43}$ Ao término de minhas observações pontuais, formularei uma definição do campo figurativo que tem relação com todo o processo social do qual me esforcei para dar conta e que inclui, conjuntamente, o trabalho do iluminador e do escriba, as passagens dos documentos textuais que ele retranscreveu, o pensamento da página que ele organiza e a concepção de certas figuras que ele arranja para sua ornamentação.

${ }^{43}$ DAMISCH, Hubert. Fenêtre jaune cadmium, op. cit., insiste nesses dispositivos e nesse "retrabalho" operado na obra de arte contemporânea, ao mesmo tempo como índice da presença material da própria obra, mas também como marca fazendo valer a imaginação do artista. Na textura do manuscrito 1 de Semur-en-Auxois, o processo em curso esboça, da mesma forma, a reflexão do artista para a elaboração de seu projeto de iluminura da inicial em estreita relação com o texto caligrafiado nas linhas marcadas no pergaminho. 
O campo é, com efeito, fruto da ordenação das iniciais traçadas sobre a pele do livro manuscrito e ele aparece na superfície nos intervalos deixados livres, os quais ele vem então preencher e mesmo, por vezes, saturar - o que hoje é difícil de perceber devido à passagem do tempo. O campo é, então, o que vive na dimensão sensível do manuscrito, em risco de desaparição permanente, em contato com o exterior e na epiderme da matéria: figurado no tecido vivo e formado de uma matéria vegetal também viva, a dos pigmentos e das plantas maceradas para extrair suas substâncias, ele traça a presença, estando presente ao olhar do monge que vê, que canta, que lê em voz alta o livro da comunidade.

A presença da letra que ordena e que vive ao ritmo da comunidade e de sua vida própria é redobrada pelo dispositivo monumental de duas duplas páginas no interior do libellus: ${ }^{44}$ na abertura, como era de se esperar, nos fólios $0 \mathrm{v}$ e $1 \mathrm{r}$ [figura 4, pág. 241], e depois, de novo, nos fólios 15v e 16r [figura 5, pág. 241], no início de uma outra seção do livro, por assim dizer, quando, em virtude da transferência das relíquias do santo fundador e de sua liturgia, a comunidade sente a necessidade de retomar e copiar a vida de Jean de Réome. Por duas vezes, quando de dois ritmos de forte intensidade na pulsação hagiográfica do mosteiro, que o levam a celebrar a memória do fundador, as duplas páginas monumentais sustentam e enquadram o elogio dos monges que sobe ao santo em uníssono, assim como na junção de todos os mundos circundantes, animal, vegetal, mineral - os da criação - , cuja presença o iluminador dá a ver pelo pensamento de sua arte. Em finas bandas, elegantes e coloridas, o acanto empresta seu movimento e seu ritmo em direção ao alto para cantar o elogio de Jean e dizer, ao modo ornamental figurado, o que as letras pintadas, de acordo com a técnica preciosa da crisografia, lembravam no interior da página (f. 0v; f. 15v). Os jogos virtuosos da letra maiúscula $V$ - Vir - integram os diferentes reinos da vida em uma natureza reconstituída com o auxílio de um vocabulário recolhido e retomado das melhores fontes da Antiguidade e que se domina porque se conhece bem (f. 1r; f. 16r). Acanto, parras, folhagens em volutas, palmetas, bestiário, cântaros, tudo aponta, de modo elevado, no gênero da retórica ilustre, para a notabilidade

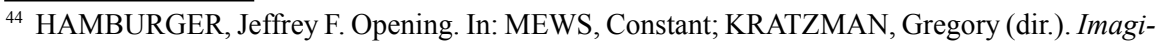
nation, books and community in medieval Europe: A Conference at the State Library of Victoria, [Actes du Colloque international de Melbourne, 29-31 mai 2008]. Melbourne: MacMillian Art Publishers, 2009, p. 50-133. Trad. parcial: Ouvertures. La double page dans les manuscrits enluminés du Moyen Âge. Dijon: Les presses du réel, 2010. Sobre o processo social de emergência da imagem medieval no livro manuscrito, em relação estreita com a substituição progressiva da definição pela descrição, RECHT, Roland. L'image médiévale. Le livre enluminé. Paris: R.M.N., 2010, em part. p. 77-164 (“L'ornement”; "L'expression"; "L'espace”). 
do homem divino cujas ações são celebradas no livro de sua vida. ${ }^{45}$ Afirmação caligráfica da presença do "homem" de Deus, vir, na interseção de vários suportes, a dupla-página incorpora todos os registros para dar a ver a todos os monges a apologia do fundador. O modo escolhido para essa exposição monumental é o de um discurso exibido em modo maior.

Tratarei agora do modo menor do discurso tecido a partir das iniciais figuradas ao longo da primeira parte do manuscrito, entre os fólios $0 \mathrm{v}$ e $35 \mathrm{r}$, porque esse discurso é o da presença da imagem, em seus traços e esquemas fundamentais. ${ }^{46}$ A cada ocorrência das iniciais vegetalizadas, observo que no desenho existe uma microestrutura que é repetida por todo lado, formando a base da percepção dessas decorações: é o motivo do nó que atrai e depois captura a atenção do espectador. Ele é bem visível na haste do $P$ de Praeterea, no fólio 3r, e no exterior das hastes da letra, como que posto sobre a linha, no $N$ de Nec dissimile huic fuit illud (...), no fólio $10 \mathrm{r} .{ }^{47}$ Para as iniciais bestializadas, isto é, trabalhadas em seu corpo pela forma do animal, que aí também se exprime e se extirpa do próprio interior da figura, ao mesmo tempo em que a faz e a desfaz, o olho do espectador é capturado, inteiramente tomado pelo encadeamento das formas seguindo um

${ }^{45}$ Um exemplo dessa presença da obra na presença do livro, o ms. BNF latin 1118, estudado por BONNE, Jean-Claude; AUBERT, Eduardo Henrik. Quand voir fait chanter. Images et neumes dans le tonaire du ms. BNF latin 1118: entre performance et performativité. In: DIERKENS, Alain; BARTHOLEYNS, Gil; GOLSENNE, Thomas (ed.). La performance des objets, op. cit., p. 225-240; em part. p. 229, n. 9, sobre o que se pode entender como "performance", "performatividade", no campo semiótico: "A performatividade de uma fórmula semiótica (de tipo descritivo ou incitativo, como aqui) só é eficaz de fato por sua recepção - de um ponto de vista pragmático; o performativo só é um optativo. A autoridade da qual ela se vale só é, de direito, um postulado que repousa sobre um processo de fé circular (...)". Mas os autores sublinham com justeza que o processo iniciado inclui na imagem tornada presente o espectador/ator, igualmente compreendido na presença do tonário, através do visual e do vocal conjugados.

${ }^{46}$ Minha análise se concentra nas iniciais dos fólios 3r, 11r, 11v, 12r, 13r, 17r, 18r, 20r, 24v, 27v e 28r. Sublinharei o fato de que todas são iniciais vegetalizadas e animalizadas, nenhuma delas é antropomórfica. Indico apenas a presença de duas figuras humanas: no fólio $52 \mathrm{v}$, na terminação da haste de um I maiúsculo - Igitur - em relação com o que se segue, vitam sancti Johannis scribere exordiar (...), tratando-se talvez da evocação em busto, na forma de um medalhão, de João; no fólio $63 \mathrm{v}$, a figura do atlante, posterior ao ano mil por seu estilo, que traz a inicial $R$ de Revolventi/ Iterum/Michi ac/Sepius prioris (...). O discurso das iniciais inscreve o libellus no seio da criação e do cosmos, desenvolvendo uma continuidade na descontinuidade das formas e das figuras, de lectio em lectio, já que cada uma das iniciais vem marcar a passagem de uma lição a outra, e ele sustenta uma verdadeira ontologia, tanto da parte do iluminador e do escriba quanto dos outros monges da comunidade. Toda percepção supõe, é verdade, uma ontologia; ver WAHL, François. Le perçu. Paris: Fayard, 2007, em part. p. 33-45, (I, cap. 1, "Du transcendantal au discursif'), na perspectiva da construção e do reconhecimento de um esquema daquilo que é percebido.

${ }^{47}$ Utilizo em meu estudo a transcrição integral do manuscrito 1 de Semur feita por Eduardo Henrik Aubert, a quem expresso aqui meus agradecimentos. 
continuum enredado e orientado, apesar de tudo, de cima para baixo, reforçando sempre a intensidade do conjunto através da fragmentação das partes. Nos dois casos, no entanto, nas iniciais vegetalizadas e nas iniciais animalizadas, as microestruturas do nó e o encadeamento enredado das partes entre si e delas com o todo, e vice-versa, a apresentação se excede em direção horizontal ao texto: por exemplo, no fólio $5 \mathrm{v}$, a inicial $R$ figurada é excedida pela ornamentação em direção à área textual vizinha, que a ladeia e que contém a frase “(...) proinde censura vigente, cum monachi sanctorum patrum aegyptiorum instituta", logo no início da lectio VI; no fólio 11r, da mesma forma, a inicial $Q$ lança o espectador em direção às letras que a completam "(...) Quodam etenim tempore loca circumadiacentia valida fames torquebat (...)", na passagem da lectio X; no fólio $11 \mathrm{v}$, o $V$ de “(...) Vir quidam nobili intentione praeventus Sequanus nomine (...)" é ornamentado com um animal cuja cauda se alonga para cima e sublinha a palavra macula logo acima dela em "(...) ne elationis macula, cumulum gratie tollat (...)", com uma terminação de linha raspada. Extrairei duas constatações desse inventário de situações entre iniciais pintadas e linhas de texto escrito. De um lado, e a observação é recorrente, as iniciais figuradas vêm sublinhar as menções de lugares de memória ou de termos históricos, mas sem conotação precisa, como pontos de referência ativos na lembrança da comunidade: o fundador Jean; os pais do deserto; o imperador Diocleciano (imperador de 284 a 305); e a grande perseguição do final do século III. De outro lado, e com menos frequência, essas iniciais podem igualmente apontar na direção de uma palavra escrita em uma ou outra linha, em relação com a apologia moral do santo fundador - aqui, no fólio $11 \mathrm{v}$, a cauda do $V$ bestializado. De certa forma, é o regime de enunciação da presença do santo entre seus monges que o iluminador/escriba arranja sem cessar na superfície do fólio: e esse regime é duplo, ele tanto indica qualidades na configuração das virtudes do santo, quanto se instaura na memória da comunidade, ativa-a, ou mesmo a reativa atualizando-a, como por ocasião da transferência das relíquias de Jean (ff. 20r e 22v), acontecimento certamente marcante. A formalização da enunciação, sua visualização em suma, passa pela associação estreita do visual ao textual, através do que chamarei de composição de áreas de ressonância entre os dois, particularmente observáveis na passagem de uma lectio em direção a outra. $\mathrm{O}$ duplo regime de enunciação faz parte, no ambiente monástico de Saint-Jean-de-Réome, do esquema da percepção que têm os monges, em um dado instante de sua história, do libellus e de sua vida no meio deles. Ele também advém, portanto, da ontologia.

Esses traços distintivos dão a perceber imediatamente toda a pertinência do esquema geral e da organização da página. Se as iniciais pintadas tecem um fio 
de unidade em sua própria diversidade e a partir dela, pode-se dizer que elas formam um verdadeiro complexo. O termo é tomado no sentido do que Carl Gustav Jung (1875-1961) e depois Sigmund Freud (1856-1939) propuseram para identificar e precisar todo o grupo de elementos representativos ligados entre si, e carregados de afetos, no seio da longa cadeia de associações induzidas e que conduzem o sujeito das experimentações a produzir uma palavra resposta a uma palavra estímulo. Os dois autores tiveram desde cedo que medir a influência deste complexo sobre o pensamento e sobre o comportamento, falando então de uma constelação. Na sequência que elas formam, mas também que elas figuram, as iniciais pintadas são um complexo suscetível de agir sobre o habitus dos monges e de participar, assim, juntamente com outros agenciamentos, da constelação de vida da comunidade, à qual elas pertencem cada vez mais. ${ }^{48}$ A presença do manuscrito e da imagem que se encontra articulada em seu seio é então ao mesmo tempo uma presença gráfica e uma presença física. Incluindo os fólios com neumas (ff. 47r-49r), o manuscrito é, mais ainda, uma presença de sons, mas no sentido barthesiano de "rumor" da língua e, finalmente, de signos. ${ }^{49}$

Em outro espaço geográfico, o norte e o centro da península italiana, da planície do Pó à do Arno, e no tempo das cidades-comunas, entre 1260 e 1366, deslocarei a análise para quatro sítios sucessivos, correspondendo a quatro grandes conventos dominicanos: na cabeça da ordem dos pregadores, como o de Bolonha, ou na cabeça das "províncias”, tais como as de Milão e Florença, sem esquecer, por sua situação de intermediário, o convento de Pisa. Examino, pois, as realizações esculpidas e pintadas, respectivamente, por Niccoló Pisano (docu-

\footnotetext{
${ }^{48}$ É por esse desvio pelos estudos de psicanálise junguiana e depois freudiana que retomarei e situarei o termo habitus, avançado em seu tempo por Pierre BOURDIEU (1930-2002), em Postface, que ele colocou no final da tradução francesa de PANOFSKY, Erwin. Architecture gothique et pensée scolastique. Paris: Minuit, 1975. Ver também, sobre esse questionamento, HOLSINGER, Bruce. The pre-modern condition, op. cit., em part. cap. 3, p. 94-113 ("Indigeneity: Panofsky, Bourdieu, and the Archaeology of the habitus"). Ao mesmo tempo, nesse tipo de dispositivo, de inicial em inicial, o iluminador/escriba organiza o reordenamento da memória dos monges e seu enriquecimento, estabelecendo, em favor das lectiones, por exemplo, mas não somente, toda uma série de conexões simples de uma figura a outra, o que equivale analogicamente à produção de causa e efeito, ou seja, tem valor de prova; sobre os fenômenos de auto-organização no domínio físico, como primeiro campo de observação, PRIGOGINE, Ilya; STENGERS, Isabelle. Entre le temps et l'éternité. Paris: Fayard, 1988. Ver também, a partir de um ponto de vista da economia geral, JORION, Paul. Comment la vérité et la réalité furent inventées. Paris: Gallimard, 2009, em part. p. 57-59, para essas hipóteses. Notarei, por fim, que Lucien Lévy-Bruhl (1857-1939) postulava dois conceitos operatórios para o que ele chamava de "mentalidade primitiva", os de "participação" e de "pertencimento", que utilizo aqui na definição do habitus dos monges de Saint-Jean-de-Réome.

49 BARTHES, Roland. Le bruissement de la langue. Essais critiques IV. Paris: Seuil/Points, 1993, sobre a literatura, a língua, o signo.
} 
mentado de 1215/1220 a 1278/1284) na igreja de São Domingos de Bolonha, na capela de São Domingos (1265-1267); por Giovanni di Balduccio (documentado de 1317 a 1349; ativo em Milão entre 1334 e 1349) na igreja de Sant'Eustorgio de Milão, na capela Portinari (1337) - ambas em escultura funerária mobiliária; depois por Francesco Traini (documentado entre 1321 e 1363) na igreja de Santa Catarina de Pisa; e por Andrea di Bonaiuto (dito Andrea da Firenze, documentado de 1343 a 1377) na igreja de Santa Maria Novella de Florença - estas últimas em pintura, respectivamente em madeira de álamo $(375 \mathrm{~cm}$ por $258 \mathrm{~cm})$, em 1340, e afresco sobre parede, em 1366-1367. Analisarei, pois, a Arca de São Domingos, a Arca de São Pedro Mártir, o Triunfo de São Tomás de Aquino e as pinturas murais da antiga sala capitular de Santa Maria Novella, em Florença, que propus chamar não mais de alegorias, mas de quadros da Igreja dominicana - a Igreja em atos, a Igreja em poder, hoje nas paredes leste e oeste da capela dos Espanhóis -, seguindo a teologia tomista e os comentários do pai Bernard Montagnes sobre a ontologia do ser em Tomás de Aquino. ${ }^{50}$ Retiro do estudo destes exemplos alguns pontos fortes que agrupo em quatro rubricas.

A primeira diz respeito também ao conceito de "presença", em relação estreita e mesmo de sinergia com o pensamento de uma ordenação eclesiástica em seu ambiente social e cultural: associados uns aos outros, os quatro sítios são a trama sobre a qual é possível definir as condições e os procedimentos pelos quais o "aparecer" pode advir, ou ser produzido - a produção de presença -, em um dado meio e momento, onde a atribuição de significado e não somente a percepção sensorial é institucionalmente o modo fundamental de abordar e, depois, de tratar o mundo. Nesse período entre os anos 1260 e meados do século XIV, a ordem dos dominicanos, no norte e no centro da Itália, exprime assim a sua "ontologia" e, portanto, seu "ser no mundo": em textos escritos, nos sermões pronunciados em público e através das encomendas de suportes visuais adaptados a suas igrejas conventuais. ${ }^{51} \mathrm{~A}$ escolha das grandes realizações monumentais recai, pois,

${ }^{50}$ RUSSO, Daniel. Des lettres sur l'image dans l'art du Moyen Âge, art. cit., em part. p. 140-141; Idem. Allégorie, analogie, paradigme. Étude sur la peinture de l'Église dominicaine par Andrea di Bonaiuto, à Florence, 1365/1367. In: HECK, Christian (dir.). L'allégorie au Moyen Âge. Turnhout: Brepols, 2011, no prelo, p. 79-94, para uma situação histórica em torno da segunda metade do século XIV, e no meio dominicano na comuna de Florença. Sobre a ontologia tomista, depois dominicana, MONTAGNES, R. P. Bernard. La doctrine de l'analogie de l'être d'après saint Thomas d'Aquin (Louvain, 1962). Paris: Cerf, 2008, em part. cap. II, p. 65-114 (“L'analogie transcendantale de l'être").

${ }^{51}$ Sobre o "aparecer", em uma "cultura da presença", em oposição a uma "cultura da significação", ver SEEL, Martin. Ästhetik des Erscheinens. Munique: Hanser, 2000. Ver também Hans-Georg Gadamer (1900-2002) nomeando, ao longo de uma entrevista, o "volume", volumen, a dimensão não 
sobre sítios de plenitude: de saber, de pregação e de poder também - e penso, certamente, na sede da Inquisição.

A segunda rubrica agrupa todo o dispositivo intencionalmente arranjado no espaço, pois se trata da presença e, portanto, do ser-no-mundo, o ser tomando o lugar da "verdade", mais precisamente do "conteúdo da verdade". ${ }^{52}$ Ora, daí resulta que o ser tem caráter de coisa, ${ }^{53}$ que ele tem substância e, sobretudo, que ele ocupa espaço: a estrutura da apresentação para o teólogo cristão é a do triunfo (Silke Tammen, 2001) e da majestade, maiestas - vide a figuração de São Tomás de Aquino tronando sobre o sol na pintura de Francesco Traini, em Pisa, ou no espaço eclesiástico, no sentido pleno do termo, no afresco pintado por Andrea di Bonaiuto, em Florence [figuras 6 e 7, págs. 243 e 244]. Ao contrário, mas em complementaridade espacial, o herético, o herege, está deitado, estendido na horizontal [Averróes - Abú al-Walìd ibn Ruchd, 1126-1198) - , por Francesco Traini] ou agachado - Averróes, no centro, Ário e Sabélio, segundo Vasari. Atentando, no entanto, para as "personagens", vemos, à esquerda, Nestório olhando para um pequeno templo, porque Cristo, segundo ele, só tomou a natureza humana para nela habitar "como em um templo", negando assim a união hipostática das duas naturezas, humana e divina, do ser; à direita, Ário, que recusou no século IV a consubstanciação do Filho com o Pai; e Averróes, ao centro, refutando a imortalidade da alma humana. Aqui, em Florença, todos os três entram em uma configuração que prolonga e conclui aquela que engloba a figura em majestade de São Tomás de Aquino e que a associa a Jesus Cristo, acima, no medalhão, e depois, ainda mais alto, no compartimento desenhado pela abóbada, a Pentecostes e ao movimento do Espírito, de cima para baixo, em direção precisamente a Tomás, e depois aos hereges, compreendidos no sopro e na revelação cristã. O ser se move, de fato, em um espaço multidimensional - tridimensional, mais exatamente -, e que subtende sua plenitude e sua majestade: vertical, dominante, do ser ao

hermenêutica do texto literário e esboçando o paralelo, a respeito da tensão entre elementos semânticos e não semânticos, com aquele que Martin Heidegger (1889-1976) estabelecia entre "mundo" e “terra", em "L'origine de l'œuvre d'art” [retomado em HEIDEGGER, Martin. Chemins qui ne mènent nulle part. Paris: Gallimard, 1962, em part. p. 41]: DUTT, Carsten. Herméneutique, esthétique, philosophie pratique, dialogue avec Hans-Georg Gadamer. Montréal: Fides, 1998, em part. p. 99.

${ }_{52}$ Comentário e análise crítica em GUMBRECHT, Hans Ulrich. Éloge de la présence. Ce qui échappe à la signification, op. cit., em part. p. 103-124.

${ }^{53}$ BOUREAU, Alain. Satan hérétique. Histoire de la démonologie (1280-1330). Paris: Odile Jacob, 2004, sobre o "character" como "ágrafo da personalidade humana", e como a marca do sacramento, em part. p. 206-207 (cap. 6, "La béance du sujet. Anthropologie scolastique de la possession”). Sobretudo, para a concepção do ser-"coisa", e sua discussão, HARMAN, Graham. L'objet quadruple. Une métaphysique des choses après Heidegger. Paris: PUF, 2010. 
ser-aí que vem ocupar todo o espaço, para aparecer; horizontal, evidência da ideia figurada - a da dominação que as figuras dos hereges experimentam, como também todas as outras figuras, tanto nos túmulos esculpidos quanto nas pinturas; é o movimento horizontal da ideia, tal como ela se apresenta na qualidade de aparecer; ${ }^{54}$ final, e o adjetivo se mostra impróprio, mas dá conta, em primeiro lugar, do movimento do ser que tende sempre ao desaparecimento - depois do surgimento em direção ao limite, como, por exemplo, na antiga sala capitular, ao leste, na parede que dá sustentação à exibição da "Igreja em atos" em que o desaparecimento se dá ao se afastar da porta, indo para o oeste, na parede do Triunfo de São Tomás, o da "Igreja em potência": desvelamento e depois dissimulação. O sítio é feito para ser visto e também compreendido como sendo o espaço do advento do ser e não o lugar. Ao longo desse processo, enfim, o herege, quase mais que o dissidente, é tocado pelo Espírito, assim como os outros, os santos e também as santas, e o Espírito é figurado na proporção do ser que se manifesta e que ocupa todo o espaço: em relação e com referência a ele. Os outros não são agentes, mas entram na "performance" do Espírito, para retomar essas noções da antropologia da agência (agency) da arte e do conceito "gelliano" de rede de arte, nexus. ${ }^{55} \mathrm{O}$ Espírito é o ponto de vista a partir do qual irradia tudo e para onde esse todo volta. ${ }^{56}$

A terceira rubrica trata do lugar da escritura - do textual - no visual, naquilo que faz a imagem esculpida ou pintada e, mais precisamente, na articulação entre os dois, portanto, no registro da enunciação mais do que no do enunciado. Observo duas modalidades particulares de articulação, uma antiga e a outra moderna, seguindo a organização imagética das realizações da segunda metade do século XIII, deixando o máximo possível de espaço para o visual. Trata-se, para a mais antiga, da forma e do tipo de titulus no interior do formato herdado do libellus; e para a mais moderna, da forma e do tipo da didascália em uma composição inteiramente em circulação, um pouco como nas tapeçarias dos séculos XV e XVI. Assim, os tituli pintados em signos gráficos visíveis/legíveis nas decorações em madeira no interior de Santa Catarina, em Pisa, no políptico de Simone Martini (1323), assim como no painel de Francesco Traini (1340) expõem os nomes das personagens escritos em pintura, algumas vezes com letras de ouro, como para

${ }^{54}$ GUMBRECHT, Hans Ulrich. Éloge de la présence, op. cit., em part. p. 112-114, refletindo sobre L'être et le temps (1927), de Martin Heidegger.

${ }^{55}$ GELL, Alfred. L'art et ses agents, une théorie anthropologique (Oxford, 1998). Dijon: Les presses du réel, 2009.

${ }^{56}$ SIMON, Gérard. Archéologie de la vision. L'optique, le corps, la peinture. Paris: Seuil, 2003, em part. p. 21-22, p. 133-137, e p. 186-187. 
figurá-los presentes à frente da moldura e sob os olhares dos irmãos e dos leigos, agentes da encomenda. As didascálias - didascalia, ensino, em grego - pintadas e figuradas nos afrescos das paredes leste e oeste da antiga sala capitular de Santa Maria Novella, em Florença (1366-1367), são relacionadas, em sua alternância com as linhas de escritura, ao interior dos livros, sendo projetadas para a vista dos irmãos e de alguns leigos, clientes habituais dos dominicanos. Dois exemplos localizados nas pinturas são bem esclarecedores:

- na parede leste, o livro de São Tomás de Aquino está aberto, no registro inferior dessa grande composição em quadro, em simetria invertida em relação ao grosso in-folio que Cristo tem na mão (direita) no topo da pintura, enquanto as didascálias interferem com as palavras reproduzidas. Estas são "figuradas" por signos visuais escritos sobre os filactérios que os profetas seguram, cada um em um medalhão: espaço fechado da palavra divina, reproduzindo o esquema de direção vertical dominante, para as três figuras à esquerda, e o esquema de direção horizontal, para as duas figuras à direita, mas em um compartimento geométrico em forma de losango. Andrea di Bonaiuto os pintou como se se tratasse de instruções vindas do exterior, de cima para baixo, feitas para serem expostas e para englobar tudo o que ocorre. O pintor colocou os profetas portando, de fato, os versículos da Bíblia sobre a Paixão e sobre a Ressurreição de Cristo. Ele não previu qualquer relação com os caracteres no interior do livro de Tomás, único livro aberto em toda a composição. Embaixo, à direita, a cena figurada expõe o Apostolado da Igreja dominicana necessário para defender a ortodoxia contra os hereges - vistos através de uma "listagem" de grupos, mais ou menos "característicos", tipificados, de nenhum modo tipológicos - e para propagar a doutrina cristã entre os que não crêem. $\mathrm{O}$ que está mais à esquerda, embaixo, Domingos, sublinha a "gestualidade" anti-herética: com uma estrela sobre a cabeça, ele atiça sua matilha (Domini canes) contra os lobos - animalização negativa dos hereges - que ameaçam as ovelhas do Senhor - animalização positiva dos "fiéis", de fides [uma das três virtudes teologais, exibida na parede oeste sobre o trono-edícula de São Tomás, vestida de branco, com uma cruz e escudo] -, seguindo as normas de apresentação de um bestiário bíblico que se tornou crístico. O seguinte, Pedro de Verona, sublinha a palavra anti-herética, com o gesto de argumentação dirigido ao grupo daqueles que não crêem, pelo menos não por enquanto eles não escutam porque não querem, ou talvez porque ainda não o ouviram: o que conta é a boa palavra, é o bom sermão, que chega à exemplaridade no martírio. O último, Tomás, prega fundamentando-se no livro aberto da 
Sabedoria face aos "gentios", aos "pagãos", que são interpretados aqui como as "pessoas" da Antiga Lei - barbas, gorros pontudos - judeus sobretudo: no fólio aberto, lê-se pintado "Veritatem meditabitur guttur meum et labia mea detestabuntur impium" ("Minha boca meditará sobre a verdade; meus lábios amaldiçoarão o ímpio"), a partir de Provérbios 8, 7, que Tomás citou como epígrafe de sua Suma contra os gentios. A "Verdade", isto é, o conteúdo da verdade, é o ser: e no alto, em simetria invertida em relação a Tomás, Cristo segura um codex fechado, de grandes proporções. Ele é o ser-aí, do qual fala Tomás para os "gentios", expondo-lhes o conteúdo da verdade;

- na parede oeste, o livro de São Tomás ocupa o centro da composição, entrando em relação visual com os livros das outras figuras e interferindo nas didascálias. A estrutura da apresentação mudou, ela passa inteiramente pela forma que se torna produtora da presença do ser, no interior de um quadro sincrético dos diferentes saberes e, sobretudo, de suas diferentes fontes de inspiração. O quadro é, com efeito, a exposição mais completa que há, para a época, da genealogia das formas do conhecimento humano diretamente sob inspiração divina. Essa genealogia, como Howard Bloch já havia sublinhado, mostra-se, ao mesmo tempo, como uma etimologia dessas formas e das figuras que as sustentam. Essas genealogia e etimologia servem de base para a produção da presença em sua plenitude espacial, portanto, em sua forma de majestade. Por uma única vez, as didascálias saem das figuras geométricas que as encerram e acompanham o movimento voltado para baixo. A partir do alto, na abóbada, para baixo, para o Cristo de braços abertos, e em seguida para a virtude da Caridade, daí para a edícula do trono, para Tomás e a clausura de seu manto negro e o brilho reluzente de seu livro e, enfim, a plataforma e os hereges ali agachados, tudo desce em uma circulação do sopro, da Palavra, que é animação de cima para baixo, e produção, na vertical, de uma fortíssima impulsão. Tomás segura diante de si o livro aberto da Sabedoria, onde estão escritas as seguintes palavras: “(...) Optavi et datus est mihi sensus et invocavi et venit in me spiritus sapientiae et praeposui illam regnis et sedibus. (...)" [“(...) Eu desejei a inteligência e ela me foi dada; eu invoquei o Senhor, e o espírito de sabedoria veio em mim; e eu o preferi aos reinos e tronos. (...)”]. A passagem das Escrituras retomada aqui assinalava o início da primeira leitura da missa para São Tomás: a liturgia, segunda meditação, junto da pintura. 
O dispositivo está aberto e permite a circulação das formas e das figuras. $\mathrm{Na}$ abóbada, após a Ascensão, Cristo intervém para a salvação da humanidade pela Missão do Espírito Santo sobre os apóstolos e depois pelo ensino dos doutores da Igreja, notadamente, entre eles, Tomás de Aquino. No topo, a pomba branca desce sobre os apóstolos reunidos em oração em torno de Maria-Templo/Igreja. A chama do Espírito está disposta sobre a cabeça de cada um deles: Maria se coloca no coração da comunidade apostólica e a figura mais elevada de autoridade é São Pedro. Abaixo, em frente à casa, judeus se amontoam para ver o que está acontecendo: poderiam ser - por que não? - as diferentes nações dos "gentios" que entraram em contato com a Igreja e sua mensagem, ao longo da história; o homem que bate à porta, por exemplo, poderia ser a figura do povo tártaro que os missionários católicos encontraram no momento em que Andrea di Bonaiuto pintava esses afrescos em Santa Maria Novella. Nas molduras, no interior dos quadrilóbulos do friso, cinco personagens trazem cartelas que narram Pentecostes a partir de versículos extraídos dos Atos dos Apóstolos. No centro do friso, Cristo, com as mãos abertas, mostra a cena vista abaixo: seus braços esboçam um movimento que se prolonga no da Caridade, em vermelho, acima da edícula. Essa edícula, por fim, poderia estar situada no prolongamento dos edifícios pintados nos painéis franciscanos da basílica de Assis, em particular a edícula que sustenta Francisco no Sonho do papa Inocêncio III (Giotto, c. 12951297). A metáfora arquitetônica, que está à obra em todo o ciclo de pinturas, trabalha também para a produção da "presença". O que está "presente" - noção próxima de prae-esse - está aí em frente, ao alcance da mão e do toque, incluindo o toque do olho. Da mesma maneira, o termo "produção" deve ser relacionado, por sua etimologia, a producere, "fazer surgir", "fazer aparecer". A produção da presença, de acordo com a análise de Hans Ulrich Gumbrecht, ${ }^{57}$ sublinha "o efeito de tangibilidade proveniente das materialidades da comunicação", um efeito "constantemente em movimento". Na parede oeste, na vasta concepção de uma Igreja dominicana "poderosa", sublinharei que se trata de uma "produção de presença em majestade", implicando um efeito espacial de tangibilidade vindo das mídias utilizadas, dos suportes da comunicação visual, no espaço de apresentação, tudo isso atravessado por movimentos de "aproximação" e de "afastamento" de grande intensidade.

${ }^{57}$ GUMBRECHT, Hans Ulrich. Éloge de la présence, op. cit., em part. p. 38-39. 
Nesse ambiente geral de signos gráficos e de figuras, inteiramente pintado em afresco, o estatuto do texto é bem singular, porque ele se situa em uma situação de comunicação original:

- é, de início, o sítio do convento de Santa Maria Novella, o lugar das duas enunciações: na vertical, a do Cristo, fonte dos versículos que o anunciam nas didascálias, e que orientam e determinam sua presença; e depois aquela, que lhe é associada como resposta e em cascata, das figuras dos dominicanos que se dirigem tanto aos fiéis quanto aos não fiéis e aos "ímpios";

- é, em seguida, o lugar dos três tipos de receptores: os dominicanos que se dirigem à terra inteira e a todos os povos, de acordo com uma perspectiva que eu chamaria de católica, no sentido original do termo; o princípio de organização suprema, o Cristo; os espectadores e, portanto, os destinatários, incluídos naquela cenografia a fim de transmitir o essencial das informações sobre a doutrina da fé.

Como no seio de uma vasta dramaturgia, onde estão situados em seu justo lugar os "hereges", a situação particular que descrevo traz uma dupla enunciação: Cristo e os dominicanos são enunciadores ao mesmo tempo, esses últimos como seus substitutos, portadores do Verbo; do mesmo modo, quando um dominicano age ou prega, seus gestos (Domingos) e suas palavras (Pedro de Verona, Tomás) são voltados para o auditório que é também o público. A presença da ausência que preenche 
o espaço o satura, com a majestade de signos que se produzem aos olhares de todos para circunscrever uma majestade visível/legível, que excede o registro do simples enunciado e se dá em extensão, no lugar, e em compreensão, na cristandade. ${ }^{58}$

A última rubrica é a da apresentação do "contemporâneo", ou mais exatamente, dos efeitos do contemporâneo nas realizações em escultura e em pintura para melhor "produzir" um efeito de clássico, isto é, de escrita clássica, um estilo. Nos túmulos dominicanos, em Bolonha e em Milão, Niccoló Pisano e, em um grau menor, Giovanni di Balduccio reformulam situações e figuras da Antiguidade clássica, talvez para melhor dar a ver as fontes antigas das encenações contemporâneas que não existiriam também sem a produção de um visibilidade acrescida de origem, arché..$^{59}$

Quando a ausência figurada no vazio descreve uma presença espacializada, como em algumas realizações em madeira pintada ao longo do século XV por artistas flamengos ou italianos, a obra inteira se cobre de sinais indicando a vida dos objetos e suas relações qualitativas no espaço. Assim, no retábulo pintado por volta de 1455 por Rogier van der Weyden para o altar da igreja de Santa Colomba, em Colônia, uma Adoração dos magos, no compartimento central, serve de suporte para um pensamento da imagem pela arte nova [figura 8 , pág. 244]. É um painel em madeira pintado a óleo (138/153 cm), hoje conservado em Munique, na Pinacoteca. A cena é pintada em uma ruína servindo de estábulo, com uma moldura arquitetônica de arco pleno coroada por um arco gótico: de acordo com Erwin Panofsky, a oposição dos estilos românico e gótico se refere

${ }^{58}$ É o tipo de regulamentação das relações entre local e global da qual, para uma certa historiografia, a perspectiva geométrica forneceria o modelo, somente a partir do início do século XV, notadamente com Filippo Brunelleschi (Florence, 1377-1446); PANOFSKY, Erwin. La perspective comme forme symbolique (Hambourg, 1924). Paris: Minuit, 1970, para quem a história da perspectiva se resume na instalação progressiva de um "espaço sistemático", permitindo ademais localizar com rigor aquele para o qual há representação no próprio espaço que ele representa para si. Ora, a análise contesta esse modelo que, do ponto de vista filosófico, eu apresentarei de outra forma: como pensar um modo de totalização que não prejulgue a existência de uma estrutura comum global no interior da qual os elementos estariam colocados como índice, mas que busca reconstruir essa estrutura, localmente, em tal ou tal sítio, assegurando, em cada caso, a possibilidade de recolar a maneira pela qual a estrutura global emerge em cada um dos pontos? Dito de outra forma, a partir de trabalhos precisos, e em uma primeira série de hipóteses, reavaliarei a abordagem local do conceito de espaço sem cessar renegociando a articulação entre local e global. DAMISCH, Hubert L'origine de la perspective. Paris: Flammarion, 1987; VINCIGUERRA, Luciano. Archéologie de la perspective. Paris: PUF, 2007; MANIGLIER, Patrice. La perspective du diable. Arles: Actes sud, 2010. Prolongamentos na filosofia das ciências, RABOUIN, David. Vivre ici. Spinoza, éthique locale. Paris: PUF, 2010, a partir da Ética (1670), e para uma reavaliação da necessidade local, aquela que se experimenta através de seus afetos que traçam uma linha para a ação quotidiana.

${ }^{59}$ Ver as reflexões de AGAMBEN, Giorgio (1942-). Qu'est-ce que le contemporain? (Veneza, 2005/2006). Paris: Rivages poche, 2008. 
ao impulso da Igreja que se eleva sobre as fundações da Sinagoga, pela vinda ao mundo, pela Encarnação, do Cristo salvador: no plano do fundo, em uma paisagem ondulada, estende-se o longo cortejo dos magos até a manjedoura: desde 1164, conservavam-se as relíquias dos magos em Colônia. No primeiro plano, as personagens principais formam uma espécie de friso. Posta em valor pela delicadeza de seu rosto e da auréola dourada e pelo azul marcante de seu manto, ligeiramente descentralizada em relação ao centro da composição, Maria, a mãe, parece se apagar face ao evento/advento (événement/avènement) que constitui o coração da cena: a homenagem do velho mago, que é também rei, face ao menino Jesus. Ele colocou seu vaso de unguento, todo em ouro, sobre um pequeno móvel de madeira, um tamborete de canto, de três pés, perto da borda da manjedoura, na direção do olho do asno e também próximo a José, que está galgando os degraus de uma escada em caracol que o leva de baixo para cima, de um espaço coberto e obscuro em direção à plataforma em plena luz, à frente da cena. Seguindo uma tradição iconográfica antiga, os magos se aproximam do Menino por um mesmo lado, um pouco como nos frisos da arte monumental dos séculos V e VI. Van der Weyden pôde, assim, ter querido mostrar as três idades da humanidade, que correspondem às três fases da evolução da vida interior: as atitudes dos magos decompõem as fases do movimento de ajoelharse e sustentam as diferentes etapas de um aprofundamento em espírito. $\mathrm{O}$ mais velho dos três pousa seus lábios na mão direita da criança; o segundo se inclina oferecendo um esplêndido cibório em ouro; o terceiro, o mais jovem, descobre a cabeça por respeito à criança que acaba de nascer e que Maria apresenta. Para os magos, que são também reis, as coroas estão nos chapéus, colocados sobre elas e circundando-as. A moda da época prima sobre a apresentação religiosa e a cobre de detalhes e anedotas do quotidiano. José está revestido com um traje daqueles anos, como os que portavam os ricos habitantes das cidades flamengas, e faz eco - um eco figurativo - com os magos, estando situado, pois, no mesmo registro de temporalidade. Ajoelhado atrás dele, o doador segura na mão um rosário, estando separado por um pequeno muro do resto da cena: um buraco se oferece aberto à vista e resulta, sem dúvida, do desabamento da abóbada, bem acima do manto azul de Maria; o espectador é assim mantido do outro lado da cena e do quadro, sendo-lhe reservado um lugar fora da composição, estendendo-se para além da moldura e do campo da pintura. O doador tem os olhos fechados, vendo a visão que se estende - materializada no compartimento central - com seus "olhos interiores", mas também em relação com São José, que sobe os degraus da escada e sai da anfractuosidade negra que está abaixo dele e que se prolonga sob a mureta. Quanto ao espectador, ele tem que vencer a distância 
espacial antes de se aproximar do quadro e de penetrar com a visão o coração do acontecimento que sugere a oferenda da missa: a "presença real" sobre o altar - Cristo estendido, oferecido (aos olhares), no "seio" de Maria - e a morte redentora que ela vem lembrar - um efeito de prolepse - o pequeno crucifixo colocado no centro da arquitetura, na enjunta entre os dois arcos plenos, acima e à direita de Maria. Deve-se ver os dois animais do mesmo modo: o asno, cujo pescoço se alonga em direção ao primeiro plano, para a cama de palha dentro da manjedoura, e o boi, cuja cabeça está voltada para Maria e que parece olhar de bem perto o que está acontecendo. A criança adorada é o salvador da humanidade, manifestação da redenção do gênero humano, mediante o sacrifício na cruz: ele deve triunfar sobre as trevas e a morte, assim como a pintura, na superfície do quadro, mostra a oposição entre o obscuro do que se estende sob a terra e a luz da cena bem exposta ao centro.

Em sua pintura, graças a seu trabalho, Rogier van der Weyden é testemunha de um processo em curso: ele compõe uma ordem, ou seja, ele imprime uma direção e também uma hierarquização entre os diferentes lugares do sítio apresentado. De espaços não diferenciados - em cima, embaixo - ele faz lugares que ele orienta, dispõe, arranja em função de um itinerário que o doador pode, ou não, tomar e seguir. Na parte de trás, uma assistência, espontânea, vinda da cidade de Belém, apressa-se para chegar diante daquele que adveio: formada pelos habitantes da cidade, ela não pertence ao cortejo dos magos - que também está em deslocamento - embora participe da dinâmica criada. Ele produz, assim, uma obra pintada inteiramente com cores, movimentos e direções na superfície do painel. O personagem devoto, de joelhos atrás da mureta, segurando seu rosário entre as mãos, em busto na pintura, seria classificado, sem dúvida demasiado rapidamente, entre as figuras de doadores, frequentemente exibidos ao longo do século XV, entre 1430 e o fim do século, sobretudo. ${ }^{60}$ Tendo em conta precisa-

${ }^{60}$ A problemática geral seria bem a do "doador na arte": ver as sínteses de HARBISON, Craig. The mirror of the artist: Northern Renaissance art in its historical context. Londres: Pearson Education, 1995 e de NASH, Susie. Northern Renaissance art. Oxford: Oxford University Press, 2008, em part. V, cap. 16, 17, 18, p. 229-288 ("Moving images", "Settings, vistas, and accoutrements for mass and prayer", "Meditation and imagination"); estudo de caso por VELDEN, Hugo van der. The donor's image: Gerard Loyet and the votive portraits of Charles the Bold. Turnhout: Brepols, 2003, considerando a problemática da arte " renascente" do norte da Europa no século XV. A questão da "figura em busto" foi levantada por CHASTEL, André. Art et humanisme à Florence au temps de Laurent le Magnifique. Paris: PUF, 1959, em part. p. 322 ss., sobre esse modo de apresentação na pintura do artista Filippo Lippi (Florença, 1406-Espoleto, 1469), levantando um certo número de perspectivas "italianas", que se encontram também na obra de Andrea Mantegna (Isola di Carturo, v. 1431-Mântua, 1506). Para a discussão dessas "perspectivas italianas", que permaneceram abertas na arte do norte da Europa, NASH, Susie. Northern Renaissance art, op. 
mente as implicações do artista na obra, seu trabalho e seu esforço para imaginar, conceber, realizar seu projeto, penso que a questão mereceria um completo reexame a partir do conceito de imagem-presença e dos modos de apresentação do espectador, repentinamente tornado um testemunho: ativo, quando ele indica o que ocorre sob seus olhos; passivo, quando ele pousa na imagem, com os olhos fechados, seu olhar voltado para si mesmo, inteiramente absorvido por sua meditação. A personagem - pois uma personagem é criada - está disposta em um lugar fechado, tão retirado quando possível do ambiente dos homens, à parte e, portanto, de forma mais passível a dar conta das emoções suscitadas. Dessa forma, ela vive ao vivo o que ela não olha, mas o que ela vê nela mesma - para si, se ela mantém os olhos fechados e abaixados; para os outros, se ela está voltada para o exterior da pintura. A modernidade do suporte intervém em muito no dispositivo adotado, e ela não deve ser separada do ofício do pintor: é, no fundo, este que cria um "pacto testemunhal", no sentido de Philippe Lejeune, que já empregava a expressão pacto, colando nela o adjetivo "autobiográfico". Por razões análogas, o pintor visa, a curto tempo, e isso também é novo, restituir toda a história (cristã) aos atores principais, os homens, entre os quais alguns são seus testemunhos, para que eles a narrem, por assim dizer, "diretamente". A presença, pois, mudou de polo de orientação: ela não é mais somente a majestade do princípio divino, manifestado em seu estar no mundo; ela se fez narrativa e mesmo, por vezes, narrativa de si, pela confrontação dominada - pelo trabalho do pintor - com o exterior e em direção ao exterior. ${ }^{61} \mathrm{O}$ que leva a testemunha a contar é o imperativo social que a transforma em profeta da coisa vista e em seu apóstolo também. De acordo com esse prisma, a confrontação com o exterior produz conhecimento sobre si e sobre os outros. Como fundamento de tudo, o pintor trabalha a expressão das emoções e das testemunhas para exibir a experiência da testemunha - daí a técnica da figura vista em busto e em grande plano - e para valorizar também o ato de fazer ver. Com Rogier van der Weyden, ou com Mantegna na Itália, assim como para os pintores dessa época, por volta de

cit., em part. I, cap. 3, p. 27-37, sobre Rogier van der Weyden, Descida da cruz, antes de 1443 ("Italian perspectives").

${ }^{61}$ Quando do processo que se segue na instalação não mais de uma presença, mas de um "testemunho", o pensamento das relações com o exterior muda e não passa mais pela instância da significação, mas por aquela de uma presença mais global no mundo ambiente - BUTLER, Judith. Le récit de soi (Fordham University Press, 2005). Paris: PUF, 2007, em part. cap. 1, p. 3-40, ("Rendre compte de soi") - para a descrição das capacidades do "sujeito" de se transformar ao mesmo tempo que o exterior sobre o qual ele age. Não posso desenvolver aqui todo o plano de fundo da crítica anticonstrutivista na qual essas reflexões estimulantes ocorrem. Contento-me, por ora, com evocá-las. 
meados do século $\mathrm{XV}$, o olho do pintor espreita o olho da testemunha que, por sua vez, atrai e capta o olho daquele ou daquela que olha, levando a seu termo o processo em curso da presença à imagem-presença. ${ }^{62}$

\section{Aberturas... para outros campos}

O conceito de imagem-presença, retirado de sua esfera de aplicação imediata, mostra-se, pois, de uma utilidade profunda para pensar as relações travadas pela imagem com seu exterior, quer ele seja o espectador, quer ele seja, ainda mais afastado, o mundo externo. Na elaboração do conceito e ao longo da análise, a filosofia e a teologia foram várias vezes solicitadas, sobretudo a primeira. Por mais que esses campos do pensamento sejam necessários para a definição compreensiva do pensamento pela arte, eles não bastariam e empurram para um deslocamento ainda maior, em direção ao campo da filosofia das ciências.

Levantarei aqui, para voltar a eles mais tarde, em outro estudo, ${ }^{63}$ dois problemas que são colocados para a imagem-presença: inicialmente, o da figuração e suas relações diversas com a não-figuração, um problema que Jean-Claude Bonne bem situou em suas pesquisas sobre a ornamentalidade, e que devo retomar fazendo referência também à antropologia social; em seguida, o da produção da imagem, no sentido do verbo prodesse, em relação com a teoria dos fluxos de imagens nas ciências da vida. Em um grande número de seus estudos sobre a ornamentalidade e o discurso do ornamento, Jean-Claude Bonne mostrou o poder da mostração (monstration) agindo nessas figuras que, frequentemente, estão no limite do não-figurativo, ao mesmo tempo em que reativam o próprio princípio de seu encadeamento. ${ }^{64}$ É interessante tentar uma aproximação com o conceito de figuração, como utilizado por Philippe Descola, para indicar, do ponto de vista da antropologia social, que

${ }^{62}$ Nesse movimento, o pensamento da imagem se exerce como imagem; MINAZZOLI, Agnes. La première ombre. Réflexion sur le miroir et la pensée. Paris: Minuit, 1990, a partir de Nicolas de Cues (1401-1464) e os pintores flamengos, notadamente Rogier van der Weyden, sobre as questões da aura do quadro e de sua falta de conclusão, em part. cap. 3-4, p. 111-171 ("L'image profonde sous l'œil vigilant du miroir", "La ressemblance à venir").

${ }^{63}$ Em preparação, com o título "L'image-présence dans l'art du Moyen Âge et la philosophie des sciences. Pour un examen problématique".

${ }^{64}$ BONNE, Jean-Claude. L'art roman de face et de profil. Le tympan de Conques. Paris: Le Sycomore, 1984; Idem; ALLIEZ, Éric. La Pensée-Matisse. Portrait de l'artiste en hyperfauve. Paris/ Nova Iorque: Le Passage/New York Éditions, 2002; ver Perspective. La revue de l'INHA, outono, 2010, n. sp., "L'ornement", para a bibliografia de seus trabalhos sobre a ornamentalidade na e da arte medieval. 
(...) diferentemente da arte, que permanece ligada a contextos históricos específicos, [uma] operação universal através da qual um objeto material qualquer é investido de forma ostensiva de uma agência socialmente definida, em virtude de uma ação de feitura, de disposição, contextualização ou de ornamentação. (...). ${ }^{65}$

Pelo conceito de figuração, trata-se de designar qualquer ação que busca "dar ao objeto um potencial de evocação icônica de um protótipo real ou imaginário que ele denota de forma indicial (...)":66 integrando esse ponto de vista, a ornamentalidade também é vista como figura indiciária de um protótipo, no mesmo nível que o suporte principal de uma imagem e, mais que ele, sem dúvida, em sua força de energia. ${ }^{67} \mathrm{O}$ segundo problema levantado consiste na abordagem dessa "fábrica de imagens", não mais nos termos históricos de afrontamentos e conflitos, mas do ponto de vista das crises internas das imagens, gerando reações em cadeia e toda a panóplia de atitudes adotadas em relação a elas: ${ }^{68}$ para além das guerras de imagens, a presença crítica das imagens nelas mesmas e, por conseguinte, nos espectadores. Em uma discussão bastante útil, Bruno Latour avança a hipótese dos fluxos de imagens construídos para a observação - "uma pausa sobre a imagem" -, sobre o modelo dos fluxos de dados submetidos aos debates nas ciências exatas, ${ }^{69}$ a fim de sublinhar o fato de que uma imagem científica tem

${ }^{65}$ DESCOLA, Philippe. L'envers du visible: ontologie et iconologie. In: Histoire de l'art et anthropologie: histoire croisée des disciplines, ['Les actes de colloques en ligne du musée du quai Branly'], http://actesbranly.revues.org/181, p. 1-12, em part. p. 2; Idem. La fabrique des images, op. cit., en part. p. 23-39, p. 73-97, p. 127-137, p. 165-183 (apresentações das quatro grandes articulações da exposição correspondendo às grandes ontologias distinguidas pelo autor, "Um mundo animado", "Um mundo objetivo", "Um mundo subdividido", "Um mundo encavalado"). Sobre as quatro ontologias, DESCOLA, Philippe. Par-delà nature et culture. Paris: Gallimard, 2005.

${ }^{66}$ Idem. L'envers du visible, art. cit., em part. p. 2. Para a discussão sobre a exposição e o catálogo, remeto à densa resenha de Eliana Magnani, nesse volume.

${ }^{67}$ Nesse sentido, ver as observações estimulantes de GOLSENNE, Thomas. L'ornement est-il animiste?. In: Histoire de l'art et anthropologie, op. cit., http://actesbranly.revues.org/282. Ver, também, RECHT, Roland. L'habitant de la sculpture. Remarques sur le locus et la perception du corps plastique". In: Histoire de l'art et anthropologie, op. cit., http://actesbranly.revues. org $/ 92$.

${ }^{68}$ LATOUR, Bruno. Sur le culte des dieux faitiches, seguido de Iconoclash. Paris: Les empêcheurs de penser en rond/La découverte, 2009, em part. p. 135-204, ("Iconoclash", [Nova Iorque, 2002]).

${ }^{69}$ O termo "fluxo", que Bruno Latour não retoma aqui, utilizando o de "cascata", em "Iconoclash", art. cit., p. 186 ss., vem de: PINCH, Trevor. Observer la nature ou observer les instruments. Culture technique, 14, 1985, p. 88-107; citado por LATOUR, Bruno. Sur le culte des dieux faitiches, seguido de Iconoclash, op. cit., p. 186, n. 41. Ver também LYNCH, Mike; WOOLGLAR, Steve (dir.). Representation in scientific practice. Cambridge, Mass.: MIT, 1990. Nesse ambiente de "cultura de laboratório", a palavra representação é mais válida que em outros lugares, em outros 
mais a ver com uma inscrição do que com uma imagem de arte contemporânea, porque ela é um "conjunto de instruções que permite alcançar a próxima", ${ }^{70} \mathrm{e}$ isso não deixa de lembrar o modelo da dupla enunciação que assinalei para as pinturas dispostas na antiga sala capitular de Santa Maria Novella, em Florença. Ademais, e seguindo o fio dessas análises, a pausa sobre a imagem é provocada por ela mesma, do interior de sua matéria e do trabalho do pintor ou do escultor: quando o espectador e hoje o visitante detêm-se face ao registro inferior da $\mathrm{Ma}$ dona das sombras de Fra Angelico, eles detectam na superfície do painel pintado uma área existencial da imagem, em outros termos, uma zona crítica, da mesma forma que os monges de Saint-Jean-de-Réome frente às iniciais figuradas ou que os fiéis imóveis, tomados pelo turbilhão da presença do ser no interior do convento dominicano, onde a liturgia reatualiza plenamente tanto a memória de Jean como a de Tomás, no seio de suas comunidades, mas a séculos de distância? Levantar a questão é, de certa forma, o mesmo que respondê-la. ${ }^{71}$

Recebido: 20/05/2011 - Aprovado: 19/09/2011.

contextos de utilização? Para um uso do termo devidamente circunstanciado no campo político, MINEUR, Didier. Archéologie de la représentation politique. Structure et fondement d'une crise. Paris: Sciences Po. Les Presses, 2010, em part. I, cap. 1-2, p. 35-144, ("Philosophie de la représentation", "L'invention du gouvernement représentatif “).

${ }^{70}$ Idem. Archéologie de la représentation politique. Structure et fondement d'une crise, op. cit., p. 186 ("Isolée, une image scientifique n'a pas de référent").

${ }^{71}$ Sobre a produção de imagens científicas, em laboratório, JONES, Caroline A.; GALISON, Peter (dir.). Picturing science, producing art. Nova Iorque: Routledge, 1998; sobre a vida em laboratório, LATOUR, Bruno; WOOLGAR, Steve. La vie de laboratoire. La production des faits scientifiques. Paris: La découverte, 1988, em part. cap. 5, p. 191-247 ("La crédibilité scientifique"). 